University of Louisville

ThinkIR: The University of Louisville's Institutional Repository

Electronic Theses and Dissertations

$5-2015$

\title{
Capital? child rape : does public opinion support the use of the death penalty on child rapists?
}

Charlene Kaye Chudacoff 1987-

University of Louisville

Follow this and additional works at: https://ir.library.louisville.edu/etd

Part of the Criminology and Criminal Justice Commons

\section{Recommended Citation}

Chudacoff, Charlene Kaye 1987-, "Capital? child rape : does public opinion support the use of the death penalty on child rapists?" (2015). Electronic Theses and Dissertations. Paper 2155.

https://doi.org/10.18297/etd/2155

This Master's Thesis is brought to you for free and open access by ThinkIR: The University of Louisville's Institutional Repository. It has been accepted for inclusion in Electronic Theses and Dissertations by an authorized administrator of ThinkIR: The University of Louisville's Institutional Repository. This title appears here courtesy of the author, who has retained all other copyrights. For more information, please contact thinkir@louisville.edu. 
CAPITAL? CHILD RAPE: DOES PUBLIC OPINION SUPPORT THE USE OF THE DEATH PENALTY ON CHILD RAPISTS?

\author{
By \\ Charlene Kaye Chudacoff \\ B.S., University of Louisville, 2011 \\ A Thesis \\ Submitted to the Faculty of the \\ College of Arts and Sciences of the University of Louisville \\ In Partial Fulfillment of the Requirements \\ For the Degree of \\ Master of Science \\ in Justice Administration \\ Department of Justice Administration \\ University of Louisville \\ Louisville, Kentucky
}

May 2015 

CAPITAL? CHILD RAPE: DOES PUBLIC OPINION SUPPORT THE USE OF THE DEATH PENALTY ON CHILD RAPISTS?

\section{By}

Charlene Kaye Chudacoff

B.S., University of Louisville, 2011

A Thesis Approved on

April 17, 2015

by the following Thesis Committee:

Thesis Director

Dr. Richard Tewksbury

Dr. Ryan Schroeder

Dr. Gennaro Vito 


\section{ACKNOWLEDGEMENTS}

The fact that I am finishing this thesis is a testament to the support I have received from some of the most important people in my life. I would like to thank my Thesis Chair, Dr. Richard Tewksbury, for his support, encouragement and patience throughout the process of writing this thesis. I asked him to be my Chair because I knew he would push me to do my best work and he did not disappoint. His guidance was invaluable to me throughout this process and I will be forever grateful. I would also like to thank the other members of my Thesis Committee, Dr. Ryan Schroeder and Dr. Gennaro Vito. A special thanks must go to Michael Losavio, if it were not for your Capital Punishment class my senior year, I would not be here today. Thank you to my other half, Daniel, for supporting me during those late nights of research and writing and rewriting. I could not have done this without you. Thank you to Petie for always being by my side and giving me moral support no matter what. You are truly my angel. Thank you to Eden for letting me do school work even when you wanted to play. You are such a sweet baby. Thank you also goes to my parents and my brother, thank you for being there for me always. Finally, thank you to all my classmates, colleagues and friends who worked alongside me these past two years. You have all inspired me to work harder every step of the way and I wish you all luck in your endeavors. 


\title{
ABSTRACT \\ CAPITAL? CHILD RAPE: DOES PUBLIC OPINION SUPPORT THE USE OF THE DEATH PENALTY ON CHILD RAPISTS?
}

\author{
Charlene Kaye Chudacoff
}

May 10, 2015

For many years scholars have quested to determine public support for the death penalty while achieving varying degrees of accuracy. Some studies have asked respondents to rate their level of agreement with the imposition of the death penalty for the crime of murder while others simply ask respondents if they agree with the use of the death penalty at all. The purpose of this thesis is to challenge oversimplification of death penalty polls while testing citizens' willingness to impose the death penalty for the crime of child rape. Two surveys were administered, one survey with statements of five different crimes of child rape without aggravating factors, the second survey with aggravating factors. Results from these surveys were analyzed against demographics for trends in sentencing selections. The main goal of this research is to further the studies on the national consensus on capital child rape statutes. 


\section{TABLE OF CONTENTS}

\section{PAGE}

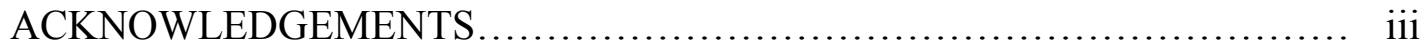

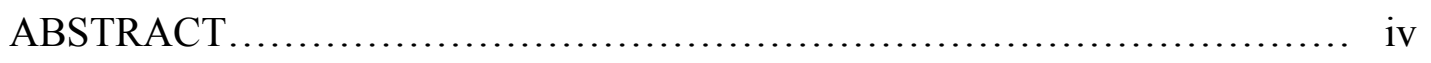

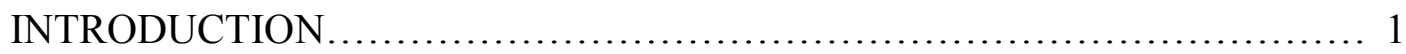

LITERATURE REVIEW ................................................... 3

Proportionality and National Consensus............................ 3

Death Penalty Statistics........................................... 10

Support for the Death Penalty.................................... 12

Retribution and Utilitarianism....................................... 18

Child Rape Statistics.............................................. 23

Special Populations, Special Protections............................ 27

The Present Study ................................................... 29

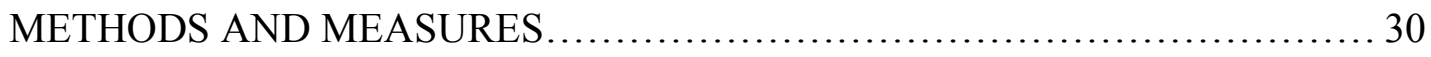

Sample ............................................................ 31

Kentucky Demographics.............................................. 35

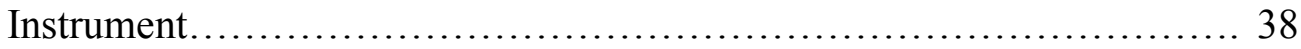

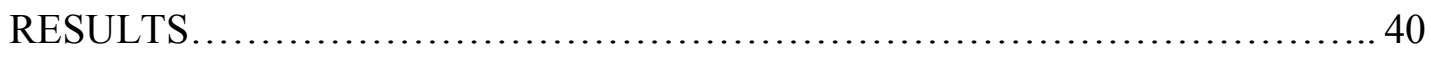

Demographics...................................................... 44

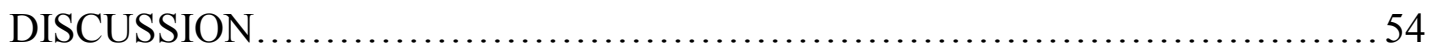

Combating Oversimplification.................................... 56 
Limitations................................................. 58

CONCLUSION ........................................................... 61

REFERENCES...................................................... 62

Cases Cited..................................................... 69

APPENDIX A....................................................... 70

CURRICULUM VITA.................................................. 78 


\section{INTRODUCTION}

Punishment is a moral requirement in response to a criminal act. We punish those who commit crimes in order to enforce the letter of the law, reset the moral balance in our communities, protect the citizens and, when possible, deter future crime. The most heinous of these offenders deserves, perhaps, an especially final brand of punishment: the death penalty. Arguably one of the most heinous possible offenses, the crime of child rape, is a battlefield upon which a war has been waged: to capitalize or not to capitalize? In the last forty-five years the death penalty has seen many changes and withstood many attacks. Capital rape and capital child rape statutes have come under fire and have, as of this date, failed to withstand the scrutiny of the Supreme Court.

Capital child rape refers specifically to the use of the death penalty in response to the crime of aggravated child rape (Bell, 2008). Child rape should be defined for these purposes as the rape of a minor child involving penetration. Aggravated child rape should be defined as child rape with the addition of one or more felonies, such as kidnapping, assault or attempted murder. Each state may differ in their description of a "child" for the purpose of a capital child rape statute, but for the purposes of this study, a child will be considered a minor of thirteen years of age or younger. This literature review will first examine the two major court cases associated with capital rape/capital child rape statutes and the Supreme Court's reasoning for their decisions on each. Death penalty statistics and support will then be reviewed, followed by an examination of a hybrid theory of 
retribution and utilitarianism that justifies the implementation of punishment, as well as an application of this theory to the current topic.

Child rape statistics will be covered to give the reader an overview of what the average victim looks like and a special populations deserving special protections argument will be introduced. The literature review will then conclude with an introduction to the present study. 


\section{LITERATURE REVIEW}

\section{Proportionality and National Consensus}

The debate over capital rape statutes has long been one of proportionality and national consensus. There have been deliberations throughout the literature and inside courtrooms for many years attempting to ascertain the true meaning of the Eighth Amendment and how it pertains to the imposition of the death penalty. The Eighth Amendment was ratified in 1791 in order to supplement the United States Constitution with a proscription of cruel and unusual punishment (Fleming, 1999). Fleming (1999) noted that it was not until 101 years later that any court made mention of proportionality. In fact, only a few years prior to the first mention of proportionality, a court opinion expressly stated that the Eighth Amendment prohibited torture or a prolonged death but did not rule out the penalty of death for any specific crimes (Fleming, 1999). Further, the first court cases that challenged the interpretation of the Eighth Amendment in favor of proportionality arguments dealt with, among other penalties, extended incarceration at hard labor for offenses such as a liquor law violation and the falsifying of an official document (Fleming, 1999). Such penalties can hardly compare with the death penalty as such offenses can hardly compare with rape and murder.

There are two key court cases that deal with capital rape crimes and statutes, Coker v. Georgia (1977) and Kennedy v. Louisiana (2008). Since the purpose of this 
research is to study public opinion on capital child rape statutes, the capital rape case of Coker v. Georgia, involving the rape of an adult woman, will be examined only as background information upon which to understand the history of the issue.

Coker v. Georgia was decided by the Supreme Court in 1977 in favor of the petitioner. Coker was a persistent felon with a prior record including murder, rape and aggravated assault (Bell, 2008; Rayburn, 2004). Upon escaping from prison, he robbed a couple in their home, raped the wife, kidnapped her and stole the couple's car. Coker was apprehended by police, stood trial and was convicted of escape, armed robbery, rape, kidnapping and motor vehicle theft (Fleming, 1999; Rayburn, 2004). The jury decided, during sentencing deliberations, that the imposition of the death penalty was appropriate under the aggravated circumstances and Coker was sentenced to die by electrocution (Bell, 2008; Rayburn, 2004). Coker argued against his conviction by appealing up to the Supreme Court on the basis that he believed the death penalty was an excessive punishment for the crime of rape. The Supreme Court agreed with Coker in spite of their internal agreement that the crime of rape, short of the taking of a life, is the "ultimate violation of self" and overturned the sentence establishing the prohibition of the imposition of the death penalty for the crime of rape against an adult woman (Coker v. Georgia 433 U.S. 598; Fleming, 1999; Flickinger, 2009).

In his concurring opinion, Justice White wrote, "Life is over for the victim of the murderer; for the rape victim, life may not be nearly so happy as it was, but it is not over and normally is not beyond repair" (Coker v. Georgia 433 U.S. 599). Justice Powell, however, dissenting in part, did not believe it appropriate to proscribe the death penalty for all rapes of adult women instead believing specific capital aggravated rape statutes 
could be viable options for the states (Flickinger, 2009). It is important to note that the dissenting opinion in Coker v. Georgia felt that the court was overstepping in striking down the capital rape statute (Fleming, 1999). In their dissenting opinions, Justices Burger and Rehnquist felt that where the death penalty may be imposed for rape, Georgia possessed the constitutional authority to do so (Fleming, 1999). In striking Coker's conviction down, the dissenting opinion believed the Supreme Court interfered with Georgia's right to govern itself as a state separate from the federal government.

In their Coker argument, the Supreme Court reasoned that since Georgia had only opted to utilize the death penalty in six out of sixty-three rape cases there must be a consensus against its use (Bell, 2009). The concurring opinion also found a national consensus against the imposition of the death penalty for rape citing that in 1971, 16 states out of 50, plus the federal government, had capital rape statutes and at the time of conviction five years post-Furman, only 3 states had reenacted capital rape statutes (Flickinger, 2009). The national consensus argument is a recurring theme in death penalty decisions. This ruling, however, only established the proscription of capital rape when the victim is an adult woman; perhaps purposefully leaving the legality of capital child rape statutes undetermined (Fraser, 2010).

Following the Coker ruling, a number of primarily southern states, including Georgia, Louisiana, South Carolina, Texas, Montana and Oklahoma, kept or enacted capital rape laws for child rapists (Bell, 2008). Mississippi's capital child rape statutes had been struck down in the 1980s but at the time of Kennedy $v$. Louisiana a number of states including Tennessee and Alabama, had capital child rape statutes under consideration (Bell, 2008). 
Capital rape again became a legal debate in the courts in 2008 when Patrick Kennedy was convicted in Louisiana of the aggravated rape of a child under 12 and sentenced to death (Adkins, 2009). Prior to Kennedy v. Louisiana, and the conviction of Richard Davis, a child rapist had not actually been put to death in the United States since 1964 (Adkins, 2009; Flickinger, 2009). Kennedy was convicted of having violently raped his eight year old stepdaughter resulting in injuries that were qualified by an expert in pediatric forensic medicine during the trial as the worst he had ever seen (Bell, 2008; Flickinger, 2009). Due to the nature of his crime, the jury convicted Kennedy and sentenced him to death. Kennedy appealed all the way up to the United States Supreme Court on the basis of Coker v. Georgia, where his sentence was overturned based on a national consensus review which revealed opposition to capital rape laws even when applied to child rape cases (Adkins, 2009).

The national consensus precedent became mandatory after Atkins v. Virginia (2002) and Roper v. Simmons (2005), which resulted in a two-step test of proportionality: "a review of legislative actions addressing the question at hand, looking for objective evidence of a national consensus on the issue" and the independent judgment of the Supreme Court (Flickinger, 2009, page 658). In deciding Kennedy v. Louisiana, the Supreme Court of Louisiana considered the number of states allowing for the execution of a child rapist as well as the "direction of change on the issue" (Flickinger, 2009, page 683). This change included states who had recently enacted capital child rape laws, and states, as well as the federal government, which allowed for the execution of those convicted of non-homicide offenses (Flickinger, 2009). The court found a trend toward a national consensus agreeing with the execution of a child rapist, and considered the first 
step of the test fulfilled (Flickinger, 2009). The court also noted that while it did not possess the independent judgment of the Supreme Court, it believed child rape could be the best non-homicide contender for the death penalty (Flickinger, 2009). In 2007, during appellate proceedings, the Louisiana Supreme Court noted that they did not perceive a national consensus that capital child rape laws constituted cruel and unusual punishment (Bell, 2008). On this note, the Supreme Court of Louisiana affirmed the lower court's sentence of death (Flickinger, 2009). This view was in stark contrast to the Supreme Court's view of the same case just months later.

The United States Supreme Court, viewing the same information, determined no national consensus toward this end and overturned Kennedy's sentence in a five to four decision in 2008 (Flickinger, 2009; Adkins, 2009; Fraser, 2010). In the majority opinion, Justice Kennedy gave focus to the moral culpability of the offender, arguing that offender culpability is lowered when the loss of life does not occur (Fraser, 2010). This, however, is very confusing as it would not be possible for an offender to accidentally rape a child. Justice Kennedy also named unreliable or made up testimony by children, giving rapists an incentive to kill and underreporting because victims of family members do not want their relatives to be put to death as additional reasons for the plurality's decision to strike down Louisiana's capital child rape statute, despite the fact that these reasons have nothing to do with an Eighth Amendment argument (Fraser, 2010). The plurality also failed to properly take under consideration the amount of harm that is done to the victim, physically, emotionally and psychologically, as well as the harm to society as a whole when a child is raped (Fraser, 2010). 
In the dissenting opinion on Kennedy, the four Justices made two important points to the purpose of this paper. First, the dissent noted that the recent decision of five states to enact capital child rape laws had "possibly marked the start of a new evolutionary line of standards" and second that the "lack of executions" for child rape were likely a result of the "halt of all executions beginning in the late 1960s" (Flickinger, page 663, 2009). For these reasons, the dissenting opinion criticized the plurality decision for having "snuffed out" the opportunity for the development of a "new evolutionary line of legislation" (Flickinger, page 663, 2009).

The majority opinion in Kennedy also refuted the possibility, stated by Justice Alito, that state legislatures had taken the Supreme Court's ruling in Coker as a proscription against any capital rape statutes, which may have accounted for states refraining from enacting capital child rape statutes post-Coker (Flickinger, 2009; Fraser, 2010). It would also seem that the Supreme Court, in looking for a national consensus, at times relies on sheer numbers of states with specific legislation and at other times relies on the direction, or trend, of legislation. In Adkins v. Virginia (2002), the Supreme Court relied on a direction of change in legislation, as opposed to the actual number of states with the legislation in question, in order to strike down death penalty statutes that applied to the developmentally disabled, however in Kennedy, the Supreme Court chose not to review the direction of change and focused precisely on the number of states with the statute in question (Fraser, 2010). Ré (2010) offered the consideration that the Supreme Court also did not place enough weight on the fact that the Federal Government itself had active non-homicide capital statutes as well as the U.S. Military's active capital child 
rape statute. He believed these statutes showed a national consensus on their own and left room for a congressional challenge to the Supreme Court's decision in the future.

A major theme throughout the literature on this subject has been the Supreme Court's reliance upon a general consensus they perceive to be against capital rape and capital child rape statutes. This reliance on a general consensus is supported by the court's interpretation of the Eighth Amendment, which bases its prohibition of cruel and unusual punishment on "the evolving standards of decency that mark the progress of a maturing society" (Bowers, page 160, 1993). The issue that arises from this reliance upon a general consensus is that frequently, it would seem, the Supreme Court has declared the public's opinion to be one way when evidence may show it is another.

One study reported that Justice Marshall challenged the consensus polls on the death penalty because of his belief that if the public were "fully informed as to the purposes of the penalty and its liabilities [it] would find the penalty shocking, unjust, and unacceptable" (Bowers, page 160, 1993). This has come to be known as the Marshall Hypothesis (Gross, 1998). In his hypothesis, Justice Marshall demonstrated that he believed his opinion to be correct, which meant the general consensus must be flawed, because he believed the public to be uninformed and therefore unable to form a trustworthy decision on the matter (Bowers, 1993).

Bohm (1999), however, interpreted Justice Marshall's hypothesis in a much different way, instead viewing Marshall's statements as supportive of death penalty polls. In his book, Bohm discussed Marshall's encouragement of citizens learning facts associated with the continued use of the death penalty. Bohm cited several studies which had attempted to demonstrate that greater knowledge of the workings of the death penalty 
would lead to lower rates of approval of the punishment, however over time most of those studies proved to be less accurate. Often, during follow ups years after the initial study, respondents had gone back to their original beliefs about capital punishment. Bohm attributed this to the emotional factors associated with death penalty beliefs. The majority opinion in Kennedy also failed to weigh whether or not it was appropriate for the Supreme Court to use its independent judgment to overturn decisions made democratically within the states by elected officials (Fraser, 2010). Reflecting on Justices Burger and Rehnquist's suggestion in their dissenting opinions on Coker, the Supreme Court's decision in Kennedy to step in and strike down these capital child rape laws may have been another infringement upon states' rights to govern themselves (Coker v. Georgia, 433 U.S. 605; Fraser, 2010). This is an issue that courts have addressed before. In the State v. Wilson (1996) majority opinion, the Louisiana Supreme Court specifically noted the importance in respecting the decision of the state legislature to modify statutes according to the evolving standards of decency (State v. Wilson, 685 So.2d 1067; Glazer, 1997). In striking down the Louisiana statute, the Supreme Court may have overstepped its bounds.

\section{Death Penalty Statistics}

The Supreme Court restored the death penalty as a legal punishment within the United States in 1976 (DeSilver, 2014). In the 38 years since, 1390 persons have been put to death, almost all by state authority (Death Penalty Information Center, 2014b; 2014c). Texas far and away leads the nation in executions with 518 as of October 29, 2014, distantly followed by Oklahoma with 111 and Virginia with 110 (Death Penalty Information Center, 2014c). At the year's end in 2012, there were 3,033 inmates on death 
row within the 36 states that authorize the use of the death penalty and federal government jurisdictions (Snell, 2014). As of the last day of 2012, all 36 state jurisdictions with death penalty statutes, as well as the federal government, authorized the use of lethal injection, while 15 of these states also offered an alternative method of execution (Snell, 2014).

While some criminals may have been sentenced to death in the past for crimes other than murder, according to the Death Penalty Information Center (2014a) no one has actually been put to death for a crime other than murder since reinstatement in 1976. Additionally, there are no current death row inmates, federal or state, who have been sentenced to die for any crime other than murder (Death Penalty Information Center, 2014a). However, non-murder statutes do still exist that allow for death penalty sentencing among the states and the federal government (Death Penalty Information Center, 2014a). The Death Penalty Information Center (2014a) lists current capital crimes such as treason (AK, CA, CO, GA, IL, LA, MS, MO, WA and the Federal Government), espionage (Federal Government), aggravated kidnapping (CO, ID, IL, MO, MT) and drug trafficking (FL, MO and the Federal Government).

Before being struck down in 2008, existing capital child rape statutes included provisions, varying by state, for offenders who assaulted children ranging in age from 14 and below to less than 10 years old (Death Penalty Information Center, 2014a). At the time of Kennedy v. Louisiana (2008), six states (GA, LA, MT, OK, SC and TX) plus the US Military had active capital child rape statutes (Death Penalty Information Center, 2014a). Five more states had pending legislation on this issue, as well, many of which died around the time Kennedy was decided by the Supreme Court (AL, CO, MS, MO TN) 
(Flickinger, 2009). If Kennedy had not interfered, those five states may have enacted their own capital child rape statutes, effectively bolstering the idea of a trend.

\section{Support for the Death Penalty}

Support for the death penalty in general has been cited as a pivotal reason behind the courts' rejection of capital rape laws (Adkins, 2009; Bell, 2008; Bowers, 1993). Throughout the years, various polls of the United States population have told very different stories about the general acceptance of the death penalty. In a 1968 court opinion, Justice Stewart cited a 1966 Gallup poll showing $42 \%$ of the population in favor of the death penalty and $47 \%$ in opposition. He compared these figures with a 1960 poll which had shown $51 \%$ favoring the death penalty and 36\% opposing it (Bowers, 1993). Justice Stewart used these figures to illustrate a diminishing population of death penalty supporters in the United States (Bowers, 1993). Over time, however, the polling results changed dramatically so that by 1987 more than $70 \%$ of Americans reported being prodeath penalty (Bowers, 1993). Important to the topic of this paper, in 1998 Gross referenced the previous year's Yankelovich Study in which respondents chose crimes they would choose to capitalize. Results of this study reported that $47 \%$ of respondents supported capitalizing the crime of rape, up from $24 \%$ in a 1991 poll, and $65 \%$ of respondents supported capitalizing the sexual molestation of children, also up from $47 \%$ in a 1991 poll.

Bohm reported on various capital punishment support studies in his 1999 book on the death penalty. Among the demographics he reported on, race was a major predictor of death penalty opinion from 1936 until 1986. Blacks were found to oppose the death penalty more often than support it and whites were found to support the death penalty 
more often than oppose it. However at the time of printing, Bohm reported studies finding that race was beginning to have less of an impact on death penalty support. Other demographic factors having an impact on death penalty opinions were income, gender, politics and the region of the country in which the respondents lived. Surprisingly, Bohm reported that Westerners were more likely to support the death penalty while Southerners were more likely to oppose it. Republicans, males and people with higher incomes were also more likely to support the death penalty during this time period, as Democrats, females and people with lower incomes were more likely to oppose it.

More recently, in 2014, Gallup reported that $63 \%$ of Americans supported the death penalty for convicted murderers while by contrast, only 33\% of Americans opposed it (Jones, 2014). When weighed against life imprisonment, the death penalty showed lower but consistent majority support with 2014 surveys showing $50 \%$ of the US population prefers the death penalty for a convicted murderer over $45 \%$ who prefer life imprisonment without parole (Jones, 2014). Bohm (1999) reported similar findings, stating that sometimes death penalty support even fell below $50 \%$ when weighed against life imprisonment without parole. Even stronger results were found in opposition to the death penalty when weighing life imprisonment without parole with restitution paid to the victim's family by the offender (Bohm, 1999). Additionally, Gallup asked respondents how they felt about the frequency of the application of the death penalty. Forty-four percent of respondents felt that the death penalty was underutilized, $26 \%$ felt it was appropriately utilized and $22 \%$ felt that it was utilized too often (Jones, 2013). These numbers have remained relatively consistent over the last decade (Jones, 2013). 
This Gallup study also looked at death penalty views according to political affiliation (Jones, 2014). While Independents and Republicans have held rather steadfast in their support of the death penalty over life imprisonment (from 56\% in 1993 to $50 \%$ in 2014 and a steady 68\% respectively), Democrats account for the largest change in support (Jones, 2014). In the last 20 years, support for the death penalty over life imprisonment among Democrats has decreased by $18 \%$ from $55 \%$ to $37 \%$ making them the only major political party to prefer life imprisonment over the death penalty for convicted murderers (Jones, 2014). However, when asked only if they support the death penalty for convicted murderers, Democrats still show $49 \%$ support over $46 \%$ opposition (Jones, 2014).

These findings are similar to Huffington Post's results from a January 2014 study on the death penalty. Their study reported that Democrats, Independents and Republicans all report a majority support for the death penalty $(51 \%, 58 \%$ and $87 \%$ respectively) (Swanson, 2014). The results also revealed that men and women tend to approve of the death penalty at very similar rates (63\% and 61\% respectively) (YouGov, 2014). Some of the largest differences were evident between races. Sixty-seven percent of whites polled favored the death penalty to some degree and $24 \%$ opposed it while $46 \%$ of blacks and $50 \%$ of Hispanics favored the death penalty compared to $29 \%$ of blacks and $33 \%$ of Hispanics who opposed it (YouGov, 2014). Keil and Vito (1991) found similar results regarding race and the death penalty. At the time of their study, blacks tended to agree less often with the use of the death penalty in comparison to whites. Their study also yielded results showing that older respondents and less educated respondents were more likely to support the death penalty because they are populations of people who consider 
their own neighborhoods to be more dangerous. Their fear directly affected their support of the death penalty as a punishment for serious crime.

The Pew Research Center reported a lower percentage of death penalty support at 55\% in its February 2014 article discussing their survey findings from early 2013; however this percentage is still evidence of a continuing majority support for the death penalty (DeSilver, 2014; Lipka, 2014). By contrast, 37\% of those polled by Pew were in opposition to the death penalty (Pew Research Center, 2013). Pew attributed the drop in death penalty support, in part, to the plummeting violent crime rate as reported by the Uniform Crime Report (DeSilver, 2014). In 1991, during a time when death penalty support reached an all time high, more than 750 violent crimes were reported per 100,000 people (DeSilver, 2014). Keil \& Vito (1991) determined at the time that people's support of the death penalty was proportionate to the amount of fear they felt within their own communities. From 1991 to 2012, violent crime has decreased more than 350 points to 386.9 violent crimes per 100,000 people (FBI, 2013).

Gallup surveys in 2014 also revealed the top reasons why death penalty proponents support the punishment (Swift, 2014). Far and away, the most cited qualifier for the death penalty, at $35 \%$, is retribution: an eye for an eye (Swift, 2014). Down from $50 \%$ in 1991, an eye for an eye still holds the top spot by a large margin, followed by a tie between saving taxpayer money (an erroneous idea) and the offender deserving the punishment as the second most commonly mentioned qualifiers, both reported at $14 \%$ (Swift, 2014). This is similar to Harris' finding in 1986 that revenge was the most often cited justification for the death penalty, and Vito and Keil's finding in 1998 that more than $70 \%$ of Kentuckians supported retribution as a justification for the death penalty. 
Deterrence, an increasingly outdated justification for the death penalty, ranks fifth on Gallup's list at 6\%, down from 13\% in 1991 (Swift, 2014).

An important factor in death penalty research is how the question of support or opposition is asked of the respondents. Often, oversimplification is present in public opinion surveys (Harris, 1986; Keil \& Vito, 1991; Vito \& Keil, 1998). Keil and Vito (1991) determined that a single measure is unable to effectively determine respondents' complex opinions on the death penalty. Additionally, Radelet and Borg (2000) stated that the public's opinion on the use of the death penalty is "highly conditional" (page 44). In response to this, the present study was inspired by a 1996 survey that sought to determine support for the death penalty as punishment for specific murder scenarios. During the 1996 study, Durham, Elrod and Kinkade cited the time's most recent Gallup Poll (1995) showing $77 \%$ of Americans polled were in favor of capital punishment. This study both tested the public's willingness to apply the death penalty to murderers when specific scenarios were given and began to gauge the way in which aggravators and mitigating factors work in regard to death penalty support (Bohm, 1999; Durham, et al., 1996). While Bowers (1993) believed that fewer people supported the death penalty than surveys reported, Durham and colleagues found that given specific scenarios people were more likely to choose to impose the death penalty than when asked favor/oppose questions such as "In general, would you say you are in favor of, against, the use of the death penalty [...] or are you not sure?"(Vito \& Keil, 1998, page 23).

Gross (1998) also compiled a list of "Support for the Death Penalty for Particular Crimes" wherein a reported $47 \%$ of respondents were in favor of the death penalty for rapists and $65 \%$ were in favor of the death penalty for child molesters. Harris (1986) and 
Durham, Elrod and Kinkade (1996) also profess to have found overwhelming support for the death penalty as punishment for the crime of murder.

A theme within the death penalty literature is a call from researchers opposing capital punishment to resist capital rape laws that can protect both adults and children and to support abolition (Rayburn, 2004; Tabak, 1998). The studies conducted on these topics rely on opinions that capital rape laws will lead to a higher rate of violent crime (Rayburn, 2004). This argument is based on the assumption that violent criminals will also murder their victims if they are aware that they are already committing a death penalty eligible offense (Glazer, 1997). Essentially, these studies presume violent criminals will feel there is nothing left to lose. This idea is erroneous since most violent criminals are not mindful of the consequences of their actions as they commit a crime. Retired Orange County Superior Court Judge Jim Gray reported on this point in his 2011 essay on death penalty facts. Gray noted that few murders are premeditated and wellplanned, and acknowledged that when most murders take place offenders are not considering the consequences. Similarly, Fagan, Geller and Zimring (2012) focused on deterrence in Texas and concluded that a "rational murderer" who weighs the pros and cons of their impending actions is more of a myth than a reality. This finding can also be applied to child rapists. The offender most often does not consider before, during, or immediately after the crime the possible consequences of his or her actions. Also important, Glazer pointed out that this rape-murder scenario is even less likely when the offender is known to the victim, which as we know most child rape perpetrators are. The murder-rape scenario is more probable for the stranger rapist, who is less common 
(Glazer, 1997). Therefore, a projection of increased violent crime due to the perpetrator fearing a death sentence is largely invalid.

Additionally, opponents of these statutes claim that capitalizing child rape could lead to fewer disclosures from abused children (Glazer, 1997). However this logic assumes that children under the age of thirteen know the possible penalties for child rape, know what a capital statute is, and understand death, all of which are far-fetched assumptions. This reasoning is likely invalid, as well.

\section{Retribution and Utilitarianism}

One of the oldest struggles associated with punishment theory continues to be fought between proponents of retribution and proponents of utilitarianism. Retributivists focus heavily on morality, the morality of committing a crime and the morality of punishing it, while Bentham's utilitarians are unconcerned with morality unless it happens to fall in line with serving the greater good. Both justifications could attempt to explain punishment for the purposes of this paper but because they do not work together, their explanations would likely fall short.

Retributive reasoning considers the past, namely the crime committed, in order to satisfy the justification for punishment (Bronsteen, 2009; Keijser, et al., 2002; Keller et al, 2010). Retributivists consider punishment as an end, opposing utilitarians who view punishment as a means to an end (Cotton, 2000; Skinner, 2012). Retribution is also rooted in morality and does not necessarily concern itself with the impact of punishment on offender or society (Bronsteen, 2009). Instead, punishment is justified in order to right a wrong and reset the moral balance in the community (Carlsmith, 2006; Keller et al, 2010; Skinner, 2012). When an offender commits a crime, he or she disrupts the balance 
in society by tipping the universe in his or her own favor at the cost of the victim's, as a result moral balance must be restored not only to the victim but to the community (Keijser, et al., 2002). This balance is restored through punishment and justice is reached by the offender receiving his just desserts (Skinner, 2012). Retribution calls for punishment because the offender has committed a transgression and there is a moral compulsion to punish those who transgress (Keijser, et al., 2002). Strelan and Van Prooijen (2013) conducted a study yielding results showing that when an offender is punished for their crime, the victim is more likely to forgive. Therefore, punishment leads to justice and justice leads to forgiveness. To knowingly allow an offender to go unpunished for his or her crime would be morally reprehensible.

There are three components that measure the immorality of a crime: the seriousness of the harm caused, the offender's intentions, and mitigating and/or aggravating circumstances (Carlsmith, 2006). Weighing all three components is helpful in determining the most appropriate punishment. Carlsmith was able to demonstrate through a series of studies that most people who choose to punish, do so based on retributive reasoning. He pinpointed that the three retributive components measuring the immorality of the crime were more important than incapacitation or deterrence factors to people tasked with punishing an offender. Information on incapacitation ranked second and deterrence ranked in a distant last place. Although his sample was relatively demographically similar, Carlsmith reported confidence that his results could be replicated with a broader sample. In order to prove this point, Keller and colleagues performed a similar study in 2010 in Europe in an attempt to replicate Carlsmith's results. Their study consisted of three studies that each built upon the last. This is significant 
because as each consecutive study was altered to control for retributive-favoring measures, the level of respondents who preferred retributive components decreased. It would appear that respondents have an interest in both retributive and utilitarian motives.

The aversion to deterrence as a useful reason to punish as found by Carlsmith comprises a growing body of literature echoed, for instance, by Choe's 2010 research on the death penalty as deterrence. Evaluating state-level data, Choe was unable to find any deterrent effect of the death penalty. Tabak (1998) also rebukes the citation of deterrence as an effective purpose for capital punishment.

Retribution and the act of rebalancing, however, are often cited as useful to society and even to the victim. In the majority opinion in Furman v. Georgia (1972), Justice Stewart affirmed the need for retribution in a civilized society. He noted that citizens need proof that their justice system is applying appropriate punishment to offenders in order to maintain law and order. He worried that a lack of visible retribution toward offenders could lead to vigilantism and anarchy.

In stark contrast to retribution, utilitarianism is future oriented, considering only the result of punishment and how it will affect the punished and the community as a unit (Bronsteen, 2009; Keijser et al., 2002; Keller et al, 2010). For a utilitarian, punishment must serve as a means to an end unlike a retributivist who would consider punishment an end in and of itself (Cotton, 2000; Skinner, 2012). Utilitarianism stipulates that punishment of the guilty should only be carried out in order to serve the greater good of the community at large, meaning that the community's benefit must outweigh the suffering of the punished. Utility is the ultimate goal, therefore punishment as deterrence, incapacitation and/or rehabilitation is not only acceptable but required when it will result 
in greater good (Bronsteen, 2009, Keijser, et al., 2002). Utilitarians, however, have no use for morality on its own; instead morality is only consequential when it simultaneously falls in line with utility (Bronsteen, 2009). An example of the importance of utility is deterrence theory. According to Paternoster (2010), deterrence theory states that a rational person will choose to commit a crime when the utility of the crime is equal to the probability of the benefits and costs of crime and non-crime. Deterrence theory strives to deter possible criminals from committing crime by decreasing the utility of crime itself by increasing severity, celerity and certainty of punishment (Paternoster, 2010; Radelet \& Borg, 2000).

In the mid twentieth century, a number of states were inspired by the Model Penal Code to adopt statements of purpose for punishment within the law (Cotton, 2000). The majority of these statements of purpose reflected utilitarian ideology and specifically left out retribution (Cotton, 2000). Over time, however, through avenues such as judicial decisions, retribution has been taken back as a statement of purpose for punishment in the United States (Cotton, 2000).

Both retributive theory and utilitarian theory offer compelling yet often opposing arguments for the purpose of punishment and for this reason the war between the two wages on. In order to utilize the best of both worlds, a mixed theory approaching the rationalization of punishment is appropriate to determine when and how punishment is applicable to criminal offenders. In his 2009 article, John Bronsteen proposed a true hybrid theory emphasizing the principles behind both retribution and utilitarianism. $\mathrm{He}$ offered two specific questions addressing punishment theory: Why does the state have the right to punish? And Why does the state choose to exercise that right? He reasoned that 
retributive theory was best suited to answer the first question. The state has the right to punish law breakers because the act of breaking the law effectively cancels said law breakers' right to not be punished (Bronsteen, 2009). By choosing to commit a crime, one, consciously or otherwise, gives up their right not to be punished in favor of pursuing illegal means. The appropriate punishment to be imposed is also supported by retributive theory. Bronsteen argued that retributive theory not only regulates the right of the state to punish but also the legitimacy of the punishment itself. Similarly, he believed utilitarian theory was properly equipped to answer the second question. The state chooses to utilize the right to punish in favor of the greater good (Bronsteen, 2009). A criminal will be punished by the state in order to satisfy the utilitarian provision that one may suffer so the majority may benefit. Therefore, punishment reinforces law abiding behavior through deterrence, incapacitation and rehabilitation and helps to maintain a civil society (Bronsteen, 2009).

This hybrid theory can be applied to the current capital child rape statutes in question. The first part of this two part theory pertains to retribution and is addressed when the offender commits the crime of rape against a child. At that time, the offender officially waves his right not to be punished. The state has the right to punish this perpetrator because he has committed a crime. This is also the portion of the process where the magnitude of harm caused to the victim, the perpetrator's intentions and any aggravating or mitigating circumstances would be assessed. Therefore, under capital child rape statutes, the state has the right to consider capital punishment as a penalty for the crime of child rape if the magnitude of harm to the victim is great, the perpetrator's intentions were clear and the aggravating circumstances (such as brutality, torture, 
threatening with a weapon, age of the child, etc.) outweigh the mitigating circumstances (perpetrator's mental state, prior abuse suffered by perpetrator, etc.).

The second part of this theory pertains to utilitarianism and is addressed when the state is faced with the choice of whether to punish the offender. In order to maintain order and promote community protection, the offender is punished for his crime by the state. Ultimately, the punishment itself can serve the purpose of retribution, incapacitation, deterrence, rehabilitation or any combination of the four. The aim of capital child rape statutes is to exercise the purposes of retribution and incapacitation on the offender who has committed the crime of child rape.

\section{Child Rape Statistics}

The National Child Abuse and Neglect Data System (NCANDS) conducts annual data collections on child abuse and neglect in the United States (NCANDS, 2012). In 2012, NCANDS estimated a total of 686,000 abused and neglected children in the country, representing a consistent decrease over the last five years. Nearly half $(46.7 \%)$ of these child victims were age 5 and below, with children under the age of 1 having the highest rate of abuse and neglect (NCANDS, 2012). Nine point three percent of abused and neglected children experienced sexual abuse and more than half (52.2\%) of these sexually abused children were age 11 or younger (NCANDS, 2012).

Because of their age and other related factors, the abuse of children under the age of twelve has been and continues to be a vastly understudied section of victim and offender research. Typical tools of crime measurement and reporting, such as the Uniform Crime Report (UCR) and the National Crime Victimization Survey (NCVS), do not account for crimes in which the victim is under the age of twelve (Snyder, 2000). A 
more recent measure of crime victimization, the National Incident-Based Reporting System (NIBRS), has been introduced in order to account, in part, for the lack of attention to and tracking of crimes committed against young children (Snyder, 2000). Unfortunately, the information base for NIBRS is only a very small percentage of the total population, making it sometimes difficult to generalize and draw conclusions about the country as a whole. Snyder (2000) was able to determine through NIBRS reports from 1991 to 1996 that one-third of reported sexual assault victims were under the age of twelve, more than $12 \%$ of forcible rapes were committed against children of this age group and the most common age of these sexual assault victims was 4 . This age group also constituted the highest percentage of multiple victim scenarios. Additionally, nearly three-quarters of child victims younger than twelve were found to be female. It is important to note that most offenders against young children are either known to the child or a family member.

Also in 2000, Smith and colleagues published a study that focused on delayed disclosure of abuse by child rape victims. Nine percent (288) of the nationally representative sample of 3,220 women interviewed reported experiencing childhood rape. Alarmingly, twenty-eight percent (81) of these women reported never having told anyone of their victimization before the survey. The 207 women who had disclosed the abuse prior to the survey most often reported it to a close friend or their mother and only twelve percent of respondents ever reported the abuse to police, social workers or clergy. Of the 236 women who remembered when they disclosed the abuse, 113 first disclosed the abuse to someone more than eight years after it took place. From the results of this study we can infer that child rape goes unreported for five years or more among nearly half of 
victims. Among the 288 self-reporting victims, the first or only sexual assault occurred at an average age of 10.9 years old. Ninety percent (259) of Smith and colleagues' respondents reported having known their abuser and seventy-three percent reported having experienced physical force at the hands of their rapist. The results of this study are pertinent because they show how often the crime of rape goes unreported to authorities. Accordingly, total reports of rape each year reflect only the tip of the proverbial iceberg. In 2005, Finkelhor and colleagues conducted a study on child victimization rates using a nationally representative sample of children and youth. The researchers were able to determine that over the course of the study year one in twelve of the sample of respondents had been sexually victimized. Additionally, girls were significantly more likely to experience sexual victimization than boys (96/1000 vs. 67/1000 respectively). More relevant to the scope of the current research, one of 1,000 children ages 2 to 5 and three of 1,000 children ages 6 to 12 had been victims of a completed or attempted rape. Most often the perpetrators of this crime were acquaintances, someone the children and their families knew, followed by strangers, then family members themselves $(85 \%, 14 \%$, and $1 \%$ respectively). Results reflected that completed or attempted rapes were more common amongst family homes with incomes falling below $\$ 20,000$ (Finkelhor, 2005). Children who experienced an attempted or completed rape also had an average of 7.3 different victimizations during the study year. In a comparison of different types of victimization, children who had been sexually victimized were at a 97\% risk of experiencing other types of abuse as well. Sexually victimized children were more likely to witness or experience indirect victimization (84\%), experience any kind of physical assault (82\%), experience property victimization (70\%) and experience any form of child 
maltreatment (43\%). A limitation of this study, however, is that adult caregivers were responsible for interviews for children ages 2 to 9, which may impact the reporting of abuse at the hands of the caregivers of the children.

In 2009, Fortier and colleagues studied child sexual abuse, coping, trauma and adult revictimization. Respondents were 99 undergraduate women from three different areas of the country who self reported having experienced childhood sexual abuse. The average age sexual abuse began for these women was 8.5 years old. During the time of abuse the average income in each respondent's family home was $\$ 50,000$ to $\$ 60,000$ per year. Of these 99 women, $40 \%$ reported having experienced sexual intercourse or some form of penetration as a child. In surveying for revictimization, the authors were able to determine that $10.9 \%$ of the respondents self reported also experiencing rape as an adult. These results evidenced that child sexual abuse can trigger avoidant coping mechanisms which then elicit trauma symptoms that finally yield sexual revictimization.

Also in 2009, Finkelhor and colleagues performed a study of child maltreatment and determined that $9.8 \%$ of children had experienced a sexual assault and the majority of child victims of sexual assault are girls. More recently in 2013, Finkelhor and colleagues published an article on child maltreatment wherein the statistics showed a two percent increase of substantiated sexual abuse cases among children under the age of 18 . However, in the past twenty years overall substantiated child sexual abuse cases have decreased by $62 \%$. It is important to note that these are cases that do not involve strangers; instead they usually pertain to parents, family members, friends, acquaintances and/or babysitters. 
In the 2010 Fourth National Incidence Study of Child Abuse and Neglect (NIS-4), Sedlak and colleagues estimated that as many as 1.25 to 3 million children were abused or neglected in the United States between 2005 and 2006. Down 19\% from the NIS-3 (1993), this corresponds to between 1 in 58 and 1 in 25 children. Of these abused and neglected children, between 135,300 and 180,500 were sexually abused, most of them girls. The NIS-4 also revealed that most child abuse and neglect cases are not investigated by Child Protective Services.

\section{Special Populations, Special Protections}

Logical reasoning exists behind capital child rape laws that courts have found to be viable in the past. In one of the strongest arguments for this, the Louisiana Supreme Court upheld its capital child rape law in favor of the special populations argument in State v. Wilson (1996) which held that "[c]hildren are a class of people that need special protection" because they are incapable of defending themselves against assaults (Bell, page 11, 2008; Fleming, 1999). The court's opinion stated that the "[r]ape of a child less than twelve years of age is like no other crime," asserting the validity of the capital child rape law, and deemed the criminal act "grossly intrusive" (Bell, page 11, 2008; Glazer, 1997). The court concluded that the crime of child rape is not a minor offense, and deserves severe punishment (State v. Wilson, 685 So.2d 1070; Fleming, 1999). Additionally, the physical, emotional and psychological trauma incurred by victims of child rape is insurmountable (Glazer, 1997; Fleming, 1999).

The special protections that should be afforded children are even more necessary when considering the perpetrators of sexual crimes against them. Most often these offenders consist of acquaintances, friends and family members, people who children are 
taught to trust and obey (Glazer, 1997; Fleming, 1999; Finkelhor, 2013). Glazer (1997) reported on factors that affect the amount of trauma a child may experience, two of these factors, the type and length of the relationship the victim has with the perpetrator, are extremely important to the special populations argument. The closer the relationship the child has with the perpetrator, the more trauma that child is likely to experience when abused. Similarly, the longer the relationship the child has with the perpetrator, the higher the likelihood that abuse will produce more severe trauma. These can consist of shorter relationships with family friends or acquaintances on one end of the spectrum, all the way to extended, close relationships with family members such as a parent or a grandparent. This trauma can eventually lead to extensive personal issues such as antisocial behavior, drug and/or alcohol addiction, psychiatric illness and suicide attempts as well as societal issues such as prostitution and victim turned sex offending (Glazer, 1997). Child sexual abuse creates a lasting cycle of abuse, offending and trauma.

Additionally, a requirement of the courts in order to hand down a death sentence is a review of the intent of the offender. The court pointed out in State v. Wilson (1996) that the rape of a child is not accidental; however the Supreme Court rejects a high standard of culpability if no loss of life results from the crime (Fleming, 1999). Because of this distinction, the culpability of the offender cannot be taken into consideration in order to impose a death sentence. This impedes the ability of the justice system to protect children who have a right to special protection under the law. Because of their inability to protect themselves, the state must be responsible for the safety and protection of children (State v. Wilson, 685 So.2d 1067). This protection should include the severe punishment 
of perpetrators who offend against children in such injurious and intrusive manners in order to properly combat the harm caused by the offender.

\section{The Present Study}

An important theme throughout the literature that the present study aims to combat is oversimplification of death penalty beliefs. As Durham and colleagues (1996) found, polling questions requiring a nominal response are limiting and generally oversimplified. The question of "Do you believe in the Death Penalty?" is unable to elicit a detailed response. Often, people are willing to apply the death penalty to some cases and not to others (Harris, 1986). The present study was designed to take this and other findings of the literature review under consideration and offered respondents multiple scenarios of child rape with a range of penalties to rate. Using data from online surveys designed to test respondents' willingness to apply the death penalty to differing child rape crimes this study aims to give a better understanding of the public's opinion on capital child rape statutes. 


\section{METHODS AND MEASURES}

The author performed this study using two anonymous surveys designed through Survey Monkey. No identifying information was collected or retained regarding the respondents to these surveys. The surveys were voluntary and respondents were not compensated for their participation in any way. The purpose of these surveys was to ascertain whether public opinion supports or rejects the death penalty as a punishment for child rape and whether these opinions differ when aggravating factors are presented. Each survey will be referred to as either Survey A or Survey B throughout.

The surveys were distributed through social media avenues. Most surveys were distributed using the social networking website, Facebook. The author published two sets of posts, one for Survey A and one for Survey B, and distributed them equally among all Facebook Friends by either posting directly to their Facebook Wall or by sending a Facebook Message. Messages were only sent to Friends who did not allow direct posts to their Wall by others. Each of the two posts was assigned to a Friend at random by the author. The posts for each survey did not identify that there were two separate surveys. The author made both sets of posts as similar as possible in order to prevent respondents from trying to take both surveys. To the author's knowledge, respondents were not made aware through any other means that two surveys were in circulation. The survey opened on Friday, February 6, 2015. The survey period was two weeks, ending on Friday, 
February 20, 2015. Each day following the survey opening, the author published two general posts, or Status Updates, one for each survey to remind respondents to take the survey. The author used a snowball method of dispersing surveys to possible respondents. Survey respondents were asked to share the link to the survey they took with their Facebook Friends.

Surveys were also distributed through the social networking website, Reddit. The author published a thread under the subsection SampleSize which included both survey links. Respondents on this website were not told there were two separate surveys, but were given a choice between two links to get to the survey. This could have led respondents to believe there were two separate surveys, however given the post requirements Reddit imposes on its users this was the best way to distribute both surveys using their website.

A few surveys were also distributed via email.

\section{Sample}

In total, 445 people took the surveys. Survey A had 227 respondents and Survey B had 218 respondents. Respondents in both groups were fairly similar in reported demographics. This similarity helps the author to report confidence in the survey results.

Participants in Survey A ranged in age from 18 to 75 with a mean age of 41.04 . Participants identified themselves as female 70.4 percent of the time. The majority, 86.1 percent of the Survey A sample identified themselves as Caucasian, 5.6 percent identified as African American, 3.2 percent as Hispanic, 1.9 percent as Asian, 1.9 percent as Other 
and 1.4 percent as Native American. In total, 58.8 percent of Survey A respondents reported that they were a parent. Annual income was also examined; 29.6 percent of respondents reported their annual income last year was between $\$ 25,000$ and $\$ 50,000$, closely followed by 25.5 percent reporting between $\$ 0$ and $\$ 25,000$. Eighteen point one percent reported earning between $\$ 50,000$ and $\$ 75,000$ last year, 16.7 percent reported more than $\$ 100,000$ and 10.2 percent reported between $\$ 75,000$ and $\$ 100,000$. In regards to education, 31 percent reported their highest educational achievement as Some College and another 31 percent reported having attended Graduate School or Beyond. This was closely followed by 28.2 percent who reported having earned a College Degree. Finally, 8.3 percent reported having earned their High School Diploma or GED and 1.4 percent reported having earned Less Than a High School Diploma. Political views were gauged on an 11 point scale, 0 being Liberal and 10 being Conservative. Twenty-five percent of respondents in Survey A identified themselves as a 5, 39.8 percent identified between 0 and 4 (Liberal), and 35.1 percent identified between 6 and 10 (Conservative). As it is pertinent to this study, respondents were asked to disclose if they had been victims of rape or a sexual offense either as a child or as an adult. Twenty point eight percent of respondents in Survey A reported that they had been the victim of rape or a sexual offense as a child and 12.5 percent reported having been a victim as an adult. Of the Survey A sample, 6 percent reported having been a victim both as a child and as an adult.

Like Survey A, participants in Survey B ranged in age from 18 to 75 with a slightly higher mean of 41.36. Respondents reported being female 70.4 percent of the time in Survey B. In regards to race, 92.5 percent identified themselves as being 
Caucasian, followed by 2.5 percent who identified as Asian, 1.5 percent who identified as African American, 1.5 percent who identified as Hispanic, 1 percent as Native American and 1 percent as Other. Survey B respondents reported being parents 59.3 percent of the time. When asked about their income, 26.1 percent of participants reported their annual income for the previous year as being $\$ 25,000$ to $\$ 50,000$, followed by 21.6 percent who reported earning between $\$ 50,000$ and $\$ 75,000$ and 21.6 percent who reported earning more than $\$ 100,000$. Seventeen point one percent reported earning between $\$ 0$ and $\$ 25,000$ and 13.6 percent reported earning between $\$ 75,000$ and $\$ 100,000$. In regards to education, 43.2 percent of respondents reported their highest academic achievement was a College Degree, 24.1 percent reported having attended Some College, another 24.1 percent reported having attended Graduate School or Beyond and 8.5 percent reported having earned their High School Diploma or GED. None of the Survey B respondents reported having Less Than a High School Diploma or GED. On the same political views scale of 0 to 10, 17.6 percent of Survey B respondents identified their political views as a 5. Survey B respondents reported their political views between 0 and 4 (Liberal) 42.2 percent of the time and 40.3 percent reported their political views between 6 and 10 (Conservative). Finally 16.6 percent of Survey B respondents reported having been a victim of rape or a sexual offense as a child, 9.5 percent reported having been a victim as an adult, and 3.5 percent of the Survey B sample reported having been a victim both as a child and as an adult.

In comparing the sample from Survey A with the sample from Survey B, the ages of the respondents are remarkably similar. Survey B respondents were only .34 years 
older than Survey A respondents. This difference is not statistically significant. Both Survey A and Survey B had the same percentage of respondents who reported being female. Survey A respondents were slightly more racially diverse than Survey B respondents with 4.1 percent more respondents who identified as African American, 1.7 percent more who identified as Hispanic, .9 percent more who identified as Other, and .4 percent more who identified as Native American. Survey B had 6.4 percent more respondents who identified as Caucasian and .6 percent more respondents who identified as Asian than Survey A. This difference is not statistically significant. In Survey B, 0.5 percent more respondents reported being a parent. This difference is not statistically significant. Respondents to Survey B reported earning more money in the last year than respondents to Survey A. From Survey B, there were 8.4 percent fewer respondents who reported earning $\$ 0$ to $\$ 25,000$ last year than from Survey A and 3.5 percent fewer respondents from Survey B reported earning between $\$ 25,000$ and $\$ 50,000$. Additionally, 3.5 percent more respondents from Survey B reported the previous year's income between $\$ 50,000$ and $\$ 75,000$ than respondents from Survey A, 3.4 percent more respondents from Survey B reported earning between $\$ 75,000$ and $\$ 100,000$ and 4.9 percent more respondents from Survey B reported earning more than $\$ 100,000$. This difference is statistically significant at the .02 level. Survey B respondents also reported a slightly higher level of educational achievement than Survey A respondents. Fifteen percent more respondents to Survey B reported having earned at least a College Degree than respondents to Survey A. Survey B respondents reported having attended Graduate School or Beyond 6.9 percent less than Survey A but also reported 6.9 percent fewer had only attended Some College. Of the Survey B respondents, 0.2 percent more reported 
having earned at least a High School Diploma or GED than Survey A, and 1.4 percent fewer (none of the Survey B respondents reported this level of education) reported having earned Less Than a High School Diploma or GED. These differences are not statistically significant. Survey A respondents were 7.4 percent more likely to identify their political views as a 5, or the middle of the road. By contrast, Survey B respondents were more likely to identify their political views as leaning toward either Liberal or Conservative. Survey B respondents were 2.4 percent more likely to identify their political views as leaning toward Liberal and 5.2 percent more likely to identify as leaning toward Conservative. This difference is not statistically significant. Survey A respondents were more likely to have been victims of rape or a sexual offense. Survey A respondents reported having been a child victim 4.2 percent more than Survey B respondents. Survey A respondents also reported having been an adult victim 3 percent more than Survey B respondents. Not surprisingly, Survey A respondents also reported having been both a child and adult victim 2.5 percent more than Survey B respondents. However, these differences are not statistically significant.

\section{Kentucky Demographics}

Census data on age, biological sex and race were collected through the Kentucky State Data Center (2012) through the University of Louisville's website. As of the most recent census, in 2010, Kentucky had a reported 4,339,367 residents (KSDC, 2012). The median age was 38.1 years (KSDC, 2012). On average, the sample used for the present study was 3.2 years older than the median age of Kentucky residents. According to the census, 2,204,415 residents were female, which comes out to about 50.8 percent (KSDC, 
2012). The sample used for the present study contained 70.4 percent female respondents, which is nearly 20 percentage points more than the state demographic. Reportedly, 3,745,655 Kentucky residents were White-Not Hispanic (86.32 percent) (KSDC, 2012). On average, respondents from the present study's sample reported being white 89.3 percent of the time; this is higher than, but close to, the state demographic. This was followed by 333,075 residents of African American-Not Hispanic decent (7.68 percent) (KSDC, 2012). The African Americans who participated in the present study constituted an average of 3.55 percent of the sample, which is less than half of the state demographic. There were 132,836 residents of Hispanic decent at the time of the census (3.06 percent) (KSDC, 2012). In comparison, the present study's sample average of 2.35 percent is lower than, but close to, the state demographic. There were also 68,261 Kentucky residents comprising three categories (Native Hawaiian/Other Pacific Islander-Not Hispanic, Other Race-Not Hispanic, and Two or More Races-Not Hispanic) which would fall under Other for the purposes of this study (1.57 percent) (KSDC, 2012). The present study's sample average who reported their race as Other was 1.45 percent, a very close match to the Kentucky demographic. This was followed by 48,338 residents of Asian decent (1.11 percent) (KSDC, 2012). The present study's sample was comprised of an average of 2.2 percent Asian respondents, which is double the state demographic. Finally, the census revealed 8,642 residents of American Indian/Alaska Native-Not Hispanic decent (.20 percent) (KSDC, 2012). For the purposes of this study, this group is compared with the Native American selection on the survey. On average, the present study's survey sample was comprised of 1.2 percent Native American respondents, which is six times higher than the state demographic. 
Data from the census on education level and income were collected from the United States Census website. This information was collected during two different census periods, which will be delineated for each demographic. Data on education levels in Kentucky were collected during the 2000 census and contain information on residents age 25 and older (Bauman \& Graf, 2003). The present study contained information regarding U.S. citizens age 18 and older. According to the 2000 census, 74.1 percent of Kentucky residents 25 or older were at least a high school graduate (Bauman \& Graf, 2003). On average, 99.25 percent of respondents to the present study reported having attained this educational achievement; this is much higher than the state demographic. Forty point six percent of Kentucky residents 25 or older had completed at least some college at the time of the census (Bauman \& Graf, 2003). Alternatively, an average of 90.8 percent of the present study's sample reported having completed at least some college; this is more than double the state demographic. The census reported 17.1 percent of Kentucky residents having earned a bachelor's degree (Bauman \& Graf, 2003). The present study's sample reported an average of 63.25 percent who had earned a college degree; this is more than three and a half times higher than the state demographic. Finally, the census revealed 6.9 percent of Kentucky residents 25 years or older had obtained an advanced degree (Bauman \& Graf, 2003). The present study's sample reported an average of 27.55 percent having attended graduate school or beyond; this is .05 percent shy of four times higher than the state demographic.

Income data for Kentucky was collected during the 2013 American Community Survey (Noss, 2014). The median household income in Kentucky during 2013 was 
$\$ 43,399$ (Noss, 2014). The median personal income respondents to the present study reported having earned throughout the previous year was between $\$ 50,000$ and $\$ 75,000$. The higher rate of income, as reported by the present study's respondents, could be due, in part, to the higher level of education reported by the same respondents.

Finally, political views in Kentucky were collected by Gallup in a 2008 study. This data was based on more than 5,000 interviews conducted by the polling group (Jones, 2009). The results show that 51.6 percent of Kentuckians identify as Democrat or lean Democrat, while 38.1 percent identify as Republican or lean Republican (Jones, 2009). Political views, as reported by the present study's respondents, had a much smaller gap in support. Forty one percent of the present study's respondents reported political views that were either Liberal or leaning Liberal, while 37.7 percent reported either Conservative or leaning Conservative views. This is only a gap of 3.3 percentage points, as opposed to the 13.5 percentage point gap between political opinions in the state demographic. Gallup identified Kentucky in their article on the survey results as a Solid Democratic state (Jones, 2009). It is interesting, however, to note that in the 2008 Presidential Election, the Republican candidate won the state of Kentucky's Electoral Votes (Jones, 2009).

\section{Instrument}

Two different surveys were the available instruments for respondents to take during this study. Survey A contained five child rape scenarios, each with three possible sentences to be handed down by a judge, as well as nine demographic questions. Survey 
B possessed all of the same content as Survey A while also including aggravating factors in the five crime descriptions. In both surveys, respondents were asked to rate their level of agreement with each punishment using the Likert Scale. The four response options were 'Strongly Agree,' (coded as 1) ‘Agree,' (coded as 2) ‘Disagree,' (coded as 3) and 'Strongly Disagree' (coded as 4). A 'Neutral' option was excluded from response choices. Each criminal scenario was based on an actual recent case of child sexual abuse. Details of the crime remained the same, however names were changed. Survey A gave respondents the general outline of each crime and Survey B gave an outline with aggravating factors included.

Demographic questions were asked in order to gain an understanding of the survey respondents. All demographic questions were closed-ended except for age. Complete surveys are included in Appendix A. 


\section{RESULTS}

Overall, respondents for Survey B who received each crime scenario with aggravators were more likely to more strongly agree with sentencing each offender to the death penalty than respondents for Survey A who did not receive aggravators with each crime scenario. These differences are statistically significant for all five crime scenarios. What follows are the results from each scenario in regards to the death penalty sentencing option. Responses are coded 1 - Strongly Agree, 2 - Agree, 3 - Disagree, 4 - Strongly Disagree. Please refer to Tables $1 \mathrm{a}$ and $1 \mathrm{~b}$ for the individual $\mathrm{t}$-test used to calculate the differences between responses to Survey A and Survey B. Surveys were coded as 1.00 for Survey A and 2.00 for Survey B.

Table 1a. Group Statistics

\begin{tabular}{|lc|r|r|r|}
\hline & Survey & N & \multicolumn{1}{|l|}{ Mean } & Std. Deviation \\
\hline A judge sentences Marcus to & 1.00 & 227 & 2.8590 & 1.01643 \\
death. & 2.00 & 218 & 2.6284 & 1.07529 \\
\hline A judge sentences Paul to death. & 1.00 & 224 & 2.8304 & 1.01900 \\
& 2.00 & 213 & 2.4977 & 1.11856 \\
\hline A judge sentences Scott to death. & 1.00 & 221 & 2.9231 & .95749 \\
& 2.00 & 209 & 2.0096 & 1.12656 \\
\hline A judge sentences John to death. & 1.00 & 220 & 2.7955 & 1.07651 \\
& 2.00 & 204 & 2.5049 & 1.10305 \\
\hline A judge sentences Dennis and & 1.00 & 220 & 2.8227 & 1.03387 \\
Katherine to death. & 2.00 & 203 & 2.5813 & 1.07494 \\
\hline
\end{tabular}


Table 1b. Independent Samples t-test

\begin{tabular}{|l|r|r|r|r|}
\hline & \multicolumn{1}{|c|}{$\mathrm{T}$} & \multicolumn{1}{|c|}{ Df } & \multicolumn{1}{c|}{$\begin{array}{c}\text { Sig. (2- } \\
\text { tailed) }\end{array}$} & $\begin{array}{c}\text { Mean } \\
\text { Difference }\end{array}$ \\
\hline A judge sentences Marcus to death. & 2.325 & 443 & .020 & .23059 \\
\hline A judge sentences Paul to death. & 3.253 & 435 & .001 & .33270 \\
\hline A judge sentences Scott to death. & 9.077 & 428 & .000 & .91351 \\
\hline A judge sentences John to death. & 2.744 & 422 & .006 & .29055 \\
\hline $\begin{array}{l}\text { A judge sentences Dennis and } \\
\text { Katherine to death. }\end{array}$ & 2.354 & 421 & .019 & .24145 \\
\hline
\end{tabular}

The first scenario on both surveys involved a 47 year old man named Marcus who has admitted to his wife that he has raped their daughter and molested their son.

Respondents were asked to rate their level of agreement with a judge sentencing Marcus to death for his crime. Respondents from Survey A had a mean response of 2.86, which is leaning in the direction of disagreement. In total, 29.5 percent of Survey A respondents either agreed or strongly agreed with sentencing Marcus to the death penalty, and 70.5 percent either disagreed or strongly disagreed. In Survey B, it was revealed that Marcus' daughter is only three years old and his son is an infant who he has molested multiple times. Respondents from Survey B had a mean response of 2.63, which is also leaning in the direction of disagreement but to a lesser degree. Overall, 39 percent of Survey B respondents agreed or strongly agreed with a judge sentencing Marcus to death, while 61.1 percent disagreed or strongly disagreed. The difference between the Survey A and Survey B means is statistically significant at the .02 level. 
The second scenario described a 30 year-old married man named Paul who has raped his eight year-old step-daughter and lied to the police about the perpetrator and evidence. Respondents from Survey A had a mean response of 2.83 to a judge sentencing Paul to death. Aggravating factors were then added for Survey B, where it is revealed that the rape was brutal, requiring his step daughter to undergo major surgery to repair the extensive damage. Respondents from Survey B had a mean response of 2.50. The difference between the Survey A and Survey B means is statistically significant at the .001 level. Survey A respondents reported either agreeing or strongly agreeing with a judge sentencing Paul to death 30.3 percent of the time, while 69.6 percent disagreed or strongly disagreed. Of the Survey B respondents, 44.6 percent agreed or strongly agreed with sentencing Paul to death while 55.4 percent disagreed or strongly disagreed. In short, while Survey A respondents were more likely to disagree with sentencing Paul to the death penalty, Survey B respondents were divided.

Scenario number three was about Scott, a 25 year old single man who rapes a 13 year old girl whom he does not know. The mean response for Survey A respondents was 2.92. It is noteworthy that this was the highest mean response for all five scenarios, meaning this was the group of responses most likely to disagree with giving the perpetrator the death penalty for his crimes. Survey B then revealed that Scott abducted the 13 year old girl, raped her, then shot her in the head and left her to die, however she survived. The mean response for Survey B respondents was 2.01. Also noteworthy in this case, this was the lowest mean response for all five scenarios and the only mean response to clearly indicate the sample agreed on average with sentencing the perpetrator to death. 
The difference between the Survey A and Survey B means is statistically significant at the .000 level. Among the Survey A respondents, 26.3 percent reported agreeing or strongly agreeing with a judge sentencing Scott to the death penalty while 73.7 percent either disagreed or strongly disagreed. When aggravating factors were added, Survey B respondents reported agreeing or strongly agreeing 66 percent of the time, while only 33.9 percent reported disagreeing or strongly disagreeing.

The fourth scenario described John, a 63 year old married man who has raped two of his female relatives repeatedly over a period of more than five years. Respondents to Survey A had a mean response of 2.80. In Survey B, respondents were also told that John has threatened his victims not to tell or he would kill them, and that John is a repeat offender who was convicted of sexual assault 15 years ago. The mean response from Survey B respondents was 2.50. The difference between the Survey A and Survey B means is statistically significant at the .006 level. Of the respondents to Survey A, 31.8 percent reported that they agreed or strongly agreed with a judge sentencing John to death, while 68.2 percent reported that they disagreed or strongly disagreed. On the other hand, Survey B respondents reported agreeing or strongly agreeing with the penalty of death being handed down 43.7 percent of the time, when the other 56.4 percent reported disagreeing or strongly disagreeing.

The final scenario described a husband and wife, Dennis and Katherine, in their mid-30s who have raped and molested one of their foster children. Respondents to Survey A had a mean response of 2.82. Survey B added that the rape and molestation took place over the course of more than eight years, and the victim, who had become an 
adult, had attempted suicide several times and still suffers from depression. Survey B respondents had a mean response of 2.58. The difference between the Survey A and Survey B means is statistically significant at the .019 level. As for the breakdown of responses, 30 percent of Survey A respondents either agreed or strongly agreed with Dennis and Katherine receiving the death penalty for their crimes, while by contrast 70 percent disagreed or strongly disagreed with this punishment. When aggravators were present, 40.9 percent of Survey B respondents reported agreeing or strongly agreeing with the appropriateness of the death penalty as a punishment for the couple while 59.1 percent reported disagreeing or strongly disagreeing with this penalty.

\section{Demographics}

There are three major demographic factors that had a strong influence on participants' responses in both Survey A and Survey B. Analyzing these demographics gives us a better understanding of why people feel the way they do about the death penalty.

Political views were a statistically significant factor in the responses participants gave in regards to the death penalty. Tables $2 \mathrm{a}$ and $2 \mathrm{~b}$ demonstrate the political views as reported by Survey A respondents. Political views were broken up into two groups, those who identified themselves as 0 to 4 leaning toward Liberal views, coded as $<5.00$, and those who identified as 5 or above leaning toward Conservative views, coded as $>=5.00$. In Survey A, differences in political views showed a statistically significant change in response for all five scenarios at the .000 level. The mean differences for all fives 
scenarios was more than 0.65 . We will expect the mean differences to decrease when aggravators are added because we expect that people will be more inclined to impose a harsher penalty on criminals whose crimes we consider to be worse than others. As was expected, when aggravators were introduced for Survey B the mean differences decreased and all were less than 0.65 . However, there was still a statistically significant change in response for all five scenarios in Survey B. Tables $2 \mathrm{c}$ and $2 \mathrm{~d}$ demonstrate the political views as reported by Survey B respondents. The difference for the case of Marcus was statistically significant at the .06 level, the case of Paul was statistically significant at the .04 level, Scott at the .001 level, John also at the .001 level and Dennis and Katherine at the .000 level. For both surveys, respondents who identified their political views as less than 5 had higher mean responses, while respondents who identified as 5 or higher had lower mean responses. This means that respondents who identified themselves as Liberal were more likely to disagree with the use of the death penalty in each of the five cases and respondents who identified themselves as Conservative were more likely to agree with the use of the death penalty in the same five cases. 
Table 2a. Survey A Group Statistics

\begin{tabular}{|l|r|r|r|r|}
\hline & $\begin{array}{r}\text { What are your } \\
\text { political views? }\end{array}$ & \multicolumn{1}{|c|}{$\mathrm{n}$} & \multicolumn{1}{c|}{ Mean } & $\begin{array}{r}\text { Std. } \\
\text { Deviation }\end{array}$ \\
\hline A judge sentences Marcus to & $>=5.00$ & 152 & 2.6513 & 1.01811 \\
death. & $<5.00$ & 64 & 3.3125 & .85217 \\
\hline A judge sentences Paul to death. & $>=5.00$ & 152 & 2.5921 & 1.00565 \\
& $<5.00$ & 64 & 3.3438 & .82074 \\
\hline A judge sentences Scott to death. & $>=5.00$ & 152 & 2.7039 & .96864 \\
& $<5.00$ & 64 & 3.4063 & .72853 \\
\hline A judge sentences John to death. & $>=5.00$ & 152 & 2.5658 & 1.07143 \\
& $<5.00$ & 64 & 3.3125 & .90633 \\
\hline A judge sentences Dennis and & $>=5.00$ & 152 & 2.5855 & 1.03222 \\
Katherine to death. & $<5.00$ & 64 & 3.3594 & .82360 \\
\hline
\end{tabular}

Table 2b. Survey A Independents Samples t-test

\begin{tabular}{|c|c|c|c|c|}
\hline & $\mathrm{T}$ & Df & $\begin{array}{l}\text { Sig. (2- } \\
\text { tailed) }\end{array}$ & $\begin{array}{c}\text { Mean } \\
\text { Difference }\end{array}$ \\
\hline A judge sentences Marcus to death. & -4.564 & 214 & .000 & -.66118 \\
\hline A judge sentences Paul to death. & -5.282 & 214 & .000 & -.75164 \\
\hline A judge sentences Scott to death. & -5.210 & 214 & .000 & -.70230 \\
\hline A judge sentences John to death. & -4.886 & 214 & .000 & -.74671 \\
\hline $\begin{array}{l}\text { A judge sentences Dennis and } \\
\text { Katherine to death. }\end{array}$ & -5.324 & 214 & .000 & -.77385 \\
\hline
\end{tabular}


Table 2c. Survey B Group Statistics

\begin{tabular}{|l|r|r|r|r|}
\hline & $\begin{array}{r}\text { What are your } \\
\text { political views? }\end{array}$ & $\mathrm{N}$ & Mean & $\begin{array}{c}\text { Std. } \\
\text { Deviation }\end{array}$ \\
\hline A judge sentences Marcus to death. & $>=5.00$ & 139 & 2.5540 & 1.06440 \\
& $<5.00$ & 60 & 2.8667 & 1.06511 \\
\hline A judge sentences Paul to death. & $>=5.00$ & 139 & 2.3957 & 1.09425 \\
& $<5.00$ & 60 & 2.7500 & 1.14426 \\
\hline A judge sentences Scott to death. & $>=5.00$ & 139 & 1.8489 & 1.06263 \\
& $<5.00$ & 60 & 2.4167 & 1.21141 \\
\hline A judge sentences John to death. & $>=5.00$ & 139 & 2.3525 & 1.06229 \\
& $<5.00$ & 60 & 2.9000 & 1.11538 \\
\hline A judge sentences Dennis and & $>=5.00$ & 139 & 2.4101 & 1.04821 \\
Katherine to death. & $<5.00$ & 60 & 3.0333 & 1.00788 \\
\hline
\end{tabular}

Table 2d. Survey B Independent Samples t-test

\begin{tabular}{|l|r|r|r|r|}
\hline & $\mathrm{t}$ & Df & \multicolumn{1}{|c|}{$\begin{array}{c}\text { Sig. (2- } \\
\text { tailed) }\end{array}$} & $\begin{array}{c}\text { Mean } \\
\text { Difference }\end{array}$ \\
\hline A judge sentences Marcus to death. & -1.902 & 197 & .059 & -.31271 \\
\hline A judge sentences Paul to death. & -2.067 & 197 & .040 & -.35432 \\
\hline A judge sentences Scott to death. & -3.313 & 197 & .001 & -.56775 \\
\hline A judge sentences John to death. & -3.286 & 197 & .001 & -.54748 \\
\hline $\begin{array}{l}\text { A judge sentences Dennis and } \\
\text { Katherine to death. }\end{array}$ & -3.894 & 197 & .000 & -.62326 \\
\hline
\end{tabular}

Annual income was also a statistically significant indicator of differences in responses that participants gave in regards to the death penalty. Respondents from Survey A reported statistically significant differences in four out of the five cases when 
the income levels reported were split into two groups, those who made $\$ 50,000$ and below, coded as $<3.00$, and those who made $\$ 50,000$ or more, coded as $>=3.00$. Please refer to Tables $3 \mathrm{a}$ and $3 \mathrm{~b}$ for income as reported on Survey A. In the case of Paul, the difference in income was statistically significant at the .015 level, for Scott the difference was statistically significant at the .012 level, for John at the .001 level and also for Dennis and Katherine at the .001 level. In the case of Marcus, the difference in income was not statistically significant. The mean difference of income for each case in Survey A was between 0.22 and 0.50 . In Survey B, the mean differences dropped to between 0.16 and 0.36. This is an expected drop, as in the political views results, where the responses became more synonymous and the gap between them began to close. We can conclude that this drop was caused by the introduction of the aggravators. Results from Survey B reflected fewer statistically significant differences in responses. Please refer to Tables 3c and $3 \mathrm{~d}$ for the income as reported on Survey B. In the case of Marcus, the difference in income was statistically significant at the .017 level and for Paul the difference was statistically significant at the .069 level. The cases of Scott, John and Dennis and Katherine did not have statistically significant differences. The respondents who reported earning more than $\$ 50,000$ income in the previous year reported higher means and respondents who reported earning less than $\$ 50,000$ reported lower means. In other words, respondents who earned more than $\$ 50,000$ were more likely to disagree with the use of the death penalty in all cases and respondents who earned less than $\$ 50,000$ were more likely to agree with the use of the death penalty in those same cases. 
Table 3a. Survey A Group Statistics

\begin{tabular}{|l|r|r|r|r|}
\hline & $\begin{array}{r}\text { Before taxes, what was } \\
\text { your personal income }\end{array}$ & \multicolumn{1}{|c|}{ Mean } & Std. Deviation \\
& \multicolumn{2}{|c|}{ last year? } & & \\
\hline A judge sentences & $<3.00$ & 97 & 2.9691 & 1.01503 \\
Marcus to death. & $>=3.00$ & 97 & 3.0000 & 1.01027 \\
\hline A judge sentences Paul & $<3.00$ & 119 & 2.6639 & .96825 \\
to death. & $>=3.00$ & 97 & 3.0928 & 1.02740 \\
\hline A judge sentences & $<3.00$ & 119 & 2.7647 & .86702 \\
Scott to death. & $>=3.00$ & 97 & 3.0619 & 1.00596 \\
\hline A judge sentences John & $<3.00$ & 119 & 2.5630 & .97697 \\
to death. & $>=3.00$ & 97 & 3.0619 & 1.10958 \\
\hline A judge sentences & $<3.00$ & 119 & 2.6134 & .94444 \\
Dennis and Katherine & & & & 1.06651 \\
to death. & & & & \\
\hline
\end{tabular}

Table 3b. Survey A Independent Samples t-test

\begin{tabular}{|l|r|r|r|r|}
\hline & \multicolumn{1}{|c|}{ T } & Df & Sig (2-tailed) & $\begin{array}{c}\text { Mean } \\
\text { Difference }\end{array}$ \\
\hline A judge sentences Marcus to death. & 1.597 & 214 & .112 & .22117 \\
\hline A judge sentences Paul to death. & 2.454 & 214 & .015 & .33613 \\
\hline A judge sentences Scott to death. & 2.535 & 214 & .012 & .32808 \\
\hline A judge sentences John to death. & 3.466 & 214 & .001 & .49883 \\
\hline A judge sentences Dennis and & 3.234 & 214 & .001 & .44841 \\
Katherine to death. & & & & \\
\hline
\end{tabular}


Table 3c. Survey B Group Statistics

\begin{tabular}{|l|r|r|r|r|}
\hline & $\begin{array}{r}\text { Before taxes, what was } \\
\text { your personal income }\end{array}$ & $\mathrm{N}$ & Mean & Std. Deviation \\
& \multicolumn{2}{|c|}{ last year? } & & \\
\hline A judge sentences & $<3.00$ & 113 & 2.8053 & 1.01646 \\
Marcus to death. & $>=3.00$ & 113 & 2.6283 & 1.11255 \\
\hline A judge sentences Paul & $<3.00$ & 86 & 2.3372 & 1.07067 \\
to death. & $>=3.00$ & 113 & 2.0885 & 1.16428 \\
\hline A judge sentences Scott & $<3.00$ & 86 & 1.9302 & 1.14609 \\
to death. & $>=3.00$ & 113 & 2.5929 & 1.12502 \\
\hline A judge sentences John & $<3.00$ & 86 & 2.4186 & 1.09085 \\
to death. & $>=3.00$ & 113 & 2.6726 & 1.03028 \\
\hline A judge sentences & $<3.00$ & 86 & 2.5000 & 1.12459 \\
Dennis and Katherine to & & & & \\
death. & & & & \\
\hline
\end{tabular}

Table 3d. Survey B Independent Samples t-test

\begin{tabular}{|l|r|r|r|r|}
\hline & $\mathrm{t}$ & \multicolumn{1}{|c|}{ Df } & \multicolumn{1}{c|}{$\begin{array}{c}\text { Sig. (2- } \\
\text { tailed) }\end{array}$} & $\begin{array}{c}\text { Mean } \\
\text { Difference }\end{array}$ \\
\hline A judge sentences Marcus to death. & 2.398 & 197 & .017 & .36345 \\
\hline A judge sentences Paul to death. & 1.829 & 197 & .069 & .29111 \\
\hline A judge sentences Scott to death. & .973 & 197 & .332 & .15826 \\
\hline A judge sentences John to death. & 1.103 & 197 & .271 & .17432 \\
\hline A judge sentences Dennis and & 1.125 & 197 & .262 & .17257 \\
Katherine to death. & & & & \\
\hline
\end{tabular}


Education was the third and final major statistically significant indicator of differences in responses given by participants in both Survey A and Survey B. Educational achievements were split into two categories for the t-test. Responses indicating less than a college degree were coded as $<4.00$ and responses indicating a college degree or beyond were coded as $>=4.00$. In Survey A, different levels of educational achievement were statistically significant indicators of differences in responses for all five cases. Tables $4 \mathrm{a}$ and $4 \mathrm{~b}$ demonstrate educational achievements as reported on Survey A. Differences in responses to each of the five cases in Survey A were statistically significant at the .000 level. The mean difference for each of the cases in Survey A was more than 0.45 . When we add aggravators in Survey B, as we anticipated with both political views and annual income, the mean difference for each case drops to below 0.45 . Once again, we are able to see evidence that aggravators change the way respondents feel about imposing the death penalty even when demographics generally indicate a different response. There are also fewer cases with statistically significant factors in Survey B. Tables $4 \mathrm{c}$ and $4 \mathrm{~d}$ demonstrate educational achievements as reported in Survey B. In the case of Marcus, the difference is statistically significant at the .087 level, in the case of John, the difference is statistically significant at the .015 level and in the case of Dennis and Katherine at the .011 level. In both Survey A and Survey B, respondents who indicated having attained a higher level of education reported higher means, while respondents who indicated having attained a lower level of education reported lower means. This means that respondents who reported higher levels of educational achievement were more likely to disagree with the use of the death penalty 
in all cases, and respondents who reported lower levels of educational achievement were more likely to agree with the use of the death penalty in all the same cases.

Table 4a. Survey A Group Statistics

\begin{tabular}{|l|r|r|r|r|}
\hline & $\begin{array}{c}\text { What is the highest } \\
\text { level of education you } \\
\text { have completed? }\end{array}$ & N & Mean & Std. Deviation \\
\hline $\begin{array}{l}\text { A judge sentences Marcus } \\
\text { to death. }\end{array}$ & $>=4.00$ & 128 & 3.0703 & .89780 \\
\hline A judge sentences Paul to & $<4.00$ & 88 & 2.5227 & 1.09311 \\
death. & $>=4.00$ & 128 & 3.0391 & .89971 \\
\hline A judge sentences Scott to & $<4.00$ & 88 & 2.4886 & 1.08272 \\
death. & $>=4.00$ & 128 & 3.1094 & .81554 \\
\hline A judge sentences John to & $<4.00$ & 88 & 2.6250 & 1.07546 \\
death. & $>=4.00$ & 128 & 3.0234 & .95953 \\
\hline A judge sentences Dennis & $<4.00$ & 88 & 2.4432 & 1.15329 \\
and Katherine to death. & $>=4.00$ & 128 & 3.0469 & .91238 \\
\hline
\end{tabular}

Table 4b. Survey A Independent Samples t-test

\begin{tabular}{|l|r|r|r|r|}
\hline & $\mathrm{t}$ & Df & \multicolumn{1}{|c|}{$\begin{array}{c}\text { Sig. (2- } \\
\text { tailed) }\end{array}$} & $\begin{array}{c}\text { Mean } \\
\text { Difference }\end{array}$ \\
\hline A judge sentences Marcus to death. & 4.027 & 214 & .000 & .54759 \\
\hline A judge sentences Paul to death. & 4.063 & 214 & .000 & .55043 \\
\hline A judge sentences Scott to death. & 3.761 & 214 & .000 & .48438 \\
\hline A judge sentences John to death. & 4.019 & 214 & .000 & .58026 \\
\hline $\begin{array}{l}\text { A judge sentences Dennis and } \\
\text { Katherine to death. }\end{array}$ & 4.116 & 214 & .000 & .56960 \\
\hline
\end{tabular}


Table 4c. Survey B Group Statistics

\begin{tabular}{|l|r|r|r|r|}
\hline & $\begin{array}{r}\text { What is the highest } \\
\text { level of education you } \\
\text { have completed? }\end{array}$ & N & Mean & Std. Deviation \\
\hline A judge sentences Marcus & $>=4.00$ & 134 & 2.7388 & 1.02546 \\
to death. & $<4.00$ & 65 & 2.4615 & 1.14669 \\
\hline A judge sentences Paul to & $>=4.00$ & 134 & 2.5821 & 1.06410 \\
death. & $<4.00$ & 65 & 2.3385 & 1.21549 \\
\hline A judge sentences Scott to & $<=4.00$ & 134 & 2.0970 & 1.15602 \\
death. & $>4.00$ & 65 & 1.8615 & 1.08796 \\
\hline A judge sentences John to & $<=4.00$ & 134 & 2.6493 & 1.05672 \\
death. & $>=4.00$ & 65 & 2.2462 & 1.15962 \\
\hline A judge sentences Dennis & $<4.00$ & 65 & 2.3231 & 1.01244 \\
and Katherine to death. & & & & 1.14711 \\
\hline
\end{tabular}

Table 4d. Survey B Independent Samples t-test

\begin{tabular}{|l|r|r|r|r|}
\hline & $\mathrm{t}$ & \multicolumn{1}{|c|}{ Df } & \multicolumn{1}{|c|}{$\begin{array}{c}\text { Sig. (2- } \\
\text { tailed) }\end{array}$} & $\begin{array}{c}\text { Mean } \\
\text { Difference }\end{array}$ \\
\hline A judge sentences Marcus to death. & 1.720 & 197 & .087 & .27727 \\
\hline A judge sentences Paul to death. & 1.445 & 197 & .150 & .24363 \\
\hline A judge sentences Scott to death. & 1.373 & 197 & .171 & .23548 \\
\hline A judge sentences John to death. & 2.444 & 197 & .015 & .40310 \\
\hline $\begin{array}{l}\text { A judge sentences Dennis and } \\
\text { Katherine to death. }\end{array}$ & 2.553 & 197 & .011 & .40827 \\
\hline
\end{tabular}




\section{DISCUSSION}

Based on the data collected during this study, the presence or absence of aggravating factors has a significant impact on citizens' willingness to impose the death penalty on offenders for the crime of child rape. When aggravators are present, citizens are more likely to agree with sentencing the offender to death regardless of demographics. The data also supports the idea that demographics such as political views, education and annual income have a significant impact on whether a citizen will agree or disagree with the imposition of the death penalty. According to these results, citizens who identify themselves as leaning toward liberal in their political views, those who report having attained a higher level of education and those who report having earned a higher income in the previous year all had a higher likelihood of disagreeing with imposing a sentence of death on each of the five offenders on both surveys. Conversely, citizens who identify themselves as leaning toward conservative in their political views, citizens who report having attained a lower level of education and citizens who report having earned a lower income in the previous year all had a higher likelihood of agreeing that the death penalty was an appropriate punishment for the five child rape crimes outlined in both surveys. It is important to note, however, that despite these demographic differences when aggravators were added in Survey B, mean responses dropped in every case.

It is also important to discuss the results of this study in terms of previous 
research on demographics. Past studies have shown that age can be an important factor in death penalty beliefs. In 1991, Keil and Vito determined that older respondents were more likely to favor the death penalty because they were more likely to feel unsafe in their own neighborhoods. In the present study, older respondents were actually less likely to favor the death penalty and more likely to oppose it. This difference could be attributed to the 24 year gap between the studies. Past research has suggested that women are more likely to oppose the use of the death penalty than men, however recent Huffington Post (2014) polling results show generally similar rates of death penalty approval between men and women. The results of this study were largely in support of this more recent research. In fact, there were several instances in which women were slightly more likely to agree with the use of the death penalty than their male counterparts. However, these results were not statistically significant.

In regards to race, the present study did not support existing research. Most research suggests that blacks and other minorities are less likely to agree with the use of the death penalty and more likely to disagree with it (Bohm, 1999; YouGov, 2014). Interestingly, the present study produced results that showed little difference of opinion based on race. In fact, there were a number of times in which minorities were more likely to agree and less likely to disagree with the use of the death penalty in a specific scenario than whites. This difference, however, was not statistically significant.

Education level was also tested. In previous research, respondents reporting lower overall education levels were more likely to agree and less likely to disagree with the use of the death penalty (Keil \& Vito, 1991). This was the finding from the present study, as 
well. In most cases, the difference between education levels in regard to death penalty opinions was statistically significant. Also in agreement with prior research were the death penalty rating results according to political views. In previous research, Republicans and respondents with more conservative political views were more likely to agree and less likely to disagree with the use of the death penalty (Bohm, 1999; Jones, 2014; Swanson, 2014). The present study also produced these results. The difference between political views in regards to death penalty ratings was statistically significant in all ten scenarios.

\section{Combating Oversimplification}

A constant theme throughout the literature that has also been discussed here in detail is the oversimplification of reported death penalty beliefs and the studies that report those beliefs. The data from this study provide evidence that the specific details of each crime matter and that general facts often do not provide enough information in order to obtain a person's opinion on whether or not the death penalty is an appropriate punishment for a specific crime. This finding is reminiscent of Durham, et al.'s (1996) study measuring opinions on the death penalty for specific murder scenarios. As we were able to see by analyzing the results of both Survey A and Survey B, the opinions of respondents changed when they were given additional details of the crime, sometimes dramatically.

An excellent example of this is the case of Scott. Responses rating each participant's agreement with Scott's sentence of death in Survey A experienced the most 
dramatic level of change when the aggravators were added for Survey B. Survey A respondents were given the information that Scott had raped a 13 year old girl. Responses to Scott receiving the death penalty for his crime as explained in Survey A had the highest mean of all responses for all five scenarios in both surveys. Respondents overwhelmingly disagreed with the judge sentencing Scott to death. Survey B respondents, however, were also told that Scott had abducted the girl before he raped her and that the crime culminated when Scott shot her in the head and left her to die, they were also told that the girl survived. Survey B responses to Scott receiving the death penalty as a punishment for his crime had the lowest mean response in all five scenarios and in both surveys. In this case, respondents overwhelmingly agreed with the judge sentencing Scott to death. In both instances, the same man was on trial for the same crime; however respondents from Survey B received a more complete picture of the crime and were able to form a more informed opinion about the punishment they felt Scott should receive.

It is possible that Scott's example could be critiqued by an opponent of capital child rape statutes as misleading since one of the aggravators included in Survey B was attempted murder. Nevertheless, it is still telling that all four of the remaining cases also showed a shift in opinion. Death penalty responses to Survey A scenarios all had higher means indicating a general disagreement while responses to Survey B scenarios had consistently lower means indicating less disagreement.

These results are important because they indicate to us that many surveys on issues like the death penalty may be ineffective at determining public opinion. 


\section{Limitations}

One major limitation of this study is that there was no option offered for Life Without Parole (LWOP) on either survey. Respondents who were gathered via Facebook left comments on the links posted by the author, a number of whom expressed concern over the absence of this option. If this study could be replicated for further research, it would be a sound idea to add LWOP or LWOP plus restitution to the victim's family as a fourth sentencing option to each scenario. A study gathering this information could produce statistically significant results that differ from the results of this study.

Another limitation of concern is the way in which the surveys were distributed. It was difficult for the author to get the survey out into groups of people outside of and away from the author's circle of friends, family and acquaintances due to the nature of social media websites such as Facebook. These websites also pose another issue to possible respondents: not all social media users log into their accounts regularly. With a survey that only lasted two weeks, it is possible that many people who may have otherwise chosen to take one of the surveys, did not log into their account during that time period. Additionally, while publishing the surveys online was a convenient way of dispersing them, better luck may be had accumulating responses with a topic of this nature if surveys could be administered in person to a group of people. If this study could be improved upon and repeated, it would be interesting and informative to see what results could be gathered by administering the two surveys at ten large universities around the United States. Since political views were such a statistically significant factor in this study, universities could be chosen by the way their state voted in the most recent 
Presidential Election. This course of action could also significantly expand the study to a much larger group of respondents, thereby strengthening the author's confidence in the results.

Related to the limitation posed by the distribution method, another limitation of the present study is that it is not a representative sample of the population. Many of the survey respondents were connected in some way to the author as friends, family, or acquaintances. This precludes the ability to generalize the results of this study. The sample was predominantly female, white, more highly educated, and earning a higher income than the state demographic.

Another limitation of this study is that the addition of aggravators to a crime scenario would likely have an impact on a respondent's opinion regardless of the crime in question. One of the biggest implications of this study is that with the addition of aggravating factors, a respondent's willingness to apply a harsher penalty increases. This may not be indicative of respondents having stronger opinions about capital child rape statutes so much as it may reflect respondent's intolerance of aggravators.

A final limitation of much death penalty research, including this study, is that outside of studying death penalty juries, we cannot know exactly how people will react when faced with actually deciding the fate of another human being. It is with a much lighter heart that most people are able to express their opinions on controversial issues such as the death penalty. For a death penalty jury, however, the responsibility is real and 
the decisions made among those groups involve complex variables that were not examined by the scope of this study. 


\section{CONCLUSION}

The death penalty has always been, and always will be, a controversial issue wherein both sides have strong opinions based on deep-seated beliefs. The research findings from this study encourage further research on the effects of aggravating factors on those opinions. The data reinforce preceding research that indicates that citizens with a higher education, who earn a higher income and who identify as more Liberal than Conservative tend to disagree with the use of the death penalty. Conversely, citizens with a lower education, who earn a lower annual income and who identify as more Conservative than Liberal tend to agree with the use of the death penalty. The current study aimed to build upon this research by adding that the presence of aggravating factors has a statistically significant impact upon the opinions of citizens regardless of their demographics. This is important because it is the reported on opinions of citizens that courts have relied upon when determining the legality of capital child rape statutes. Additionally, the difference in responses between Survey A and Survey B provide us with some evidence that citizens are capable of deciding which cases of child rape are rightfully punished with the death penalty and which are not. Just as not all crimes of murder warrant the death penalty, not all cases of child rape do either. The respondents for this study were asked to note the differences between cases and rate which penalty they felt was most appropriate for each offender. Citizens deserve to have this same opportunity in the court room when presented with a new case of child rape. 


\section{REFERENCES}

Adkins, B. (2008). Constitutional law - The death penalty - Death penalty violates eighth amendment when used as punishment for the rape of a child when death does not result. Cumberland Law Review. 39 (3): 785-799.

Bauman, K. J. \& Graf, N. L. (2003, August). Educational attainment: 2000. Retrieved from United States Census Bureau website: http://www.census.gov/prod/2003 pubs/c2kbr-24.pdf

Bell, M. C. (2007). Grassroots death sentences?: The social movement for capital child rape laws. Journal of Criminal Law \& Criminology. 98 (1): 1-29.

Bohm, R. M. (1999). Deathquest: An introduction to the theory and practice of capital punishment in the United States. Cincinnati, OH: Anderson Publishing.

Bowers, W. (1993). Capital punishment and contemporary values: People's misgivings and the court's misperceptions. Law and Society Review. 27 (1): 157-75.

Bronsteen, J. (2009). Retribution's Role. Indiana Law Journal. 84 (4): 1129-1156.

Carlsmith, K. M. (2006). The roles of retribution and utility in determining punishment. Journal of Experimental Social Psychology. 42 (4): 437-451.

Choe, J. (2010). Another look at the deterrent effect of death penalty. Journal of Advanced Research in Law \& Economics. 1 (1): 12-15. 
Cotton, M. (2000). Back with a vengeance: The resilience of retribution as an articulated purpose of criminal punishment. American Criminal Law Review. 37 (4): 13131362.

Death Penalty Information Center. (2014a). Death penalty for offenses other than murder. Retrieved November 4, 2014 from http://www.deathpenaltyinfo.org /death-penalty-offenses-other-murder

Death Penalty Information Center. (2014b, October 29). Executions by year. Retrieved November 4, 2014 from http://www.deathpenaltyinfo.org/executionsyear

Death Penalty Information Center. (2014c, October 29). Number of executions by state and region since 1976. Retrieved November 4, 2014 from http://www.deathpenaltyinfo.org/number-executions-state-and-region-1976

Desilver, D. (2014, March 28). Lower support for death penalty tracks with falling crime rates, more exonerations. Pew Research Center. Retrieved from http://www.pewresearch.org/fact-tank/2014/03/28/lower-support-for-deathpenalty-tracks-with-falling-crime-rates-more-exonerations/

Durham, A. M., Elrod, H. P. \& Kinkade, P. T. (1996). Public support for the death penalty: Beyond Gallup. Justice Quarterly. 13 (4): 705-736.

Fagan, J., Geller, A., \& Zimring, F. E. (2012). The Texas deterrence muddle. Criminology \& Public Policy. 11 (3): 579-591.

Federal Bureau of Investigation. (2013). Crime in the United States, 2012: Violent crime. Uniform Crime Report. 
Finkelhor, D., Jones, L., Shattack, A \& Saito, K. (2013). Updated Trends in Child Maltreatment, 2012. Durham, N.H.: Crimes Against Children Research Center.

Finkelhor, D., Ormrod, R., Turner, H. \& Hamby, S. L. (2005). The victimization of children and youth: A comprehensive, national survey. Child Maltreatment. 10 (1): 5-25.

Finkelhor, D., Turner, H., Ormrod, R. \& Hamby, S. L. (2009). Violence, abuse, and crime exposure in a national sample of children and youth. Pediatrics. 124 (5): $1411-1423$.

Fleming, A. F. (1999). Louisiana's newest capital crime: The death penalty for child rape. Journal of Criminal Law \& Criminology. 89 (2): 717-750.

Flickinger, B. J. (2009). Kennedy v. Louisiana: The United States Supreme Court erroneously finds a national consensus against the use of the death penalty for the crime of child rape. Creighton Law Review. 42 (4): 655-687.

Fortier, M., DiLillo, D., Messman-Moore, T. L., Peugh, J., DeNardi, K. A. \& Gaffey, K. J. (2009). Severity of child sexual abuse and revictimization: The mediating role of coping and trauma symptoms. Psychology of Women Quarterly. 33 (3):308320.

Fraser, L. (2010). Supreme Court finds an inexact consensus to spare child rapists: A critical examination of Kennedy v. Louisiana. Houston Law Review. 47 (1): 215244.

Glazer, Y. (1997). Child rapists beware! The death penalty and Louisiana's amended aggravated rape statute. American Journal of Criminal Law. 25 (79): 79-114. 
Gray, J. P. (2011). Essay: Facing the facts on the death penalty. Loyola of Los Angeles Law Review. 44: 255-264.

Gross, S. R. (1998). Update: American public opinion on the death penalty - It's getting personal. Cornell Law Review. 83 (6): 1448-1475.

Harris, P.W. (1986). Oversimplification and error in public opinion surveys on capital punishment. Justice Quarterly. 3 (4):429-455.

Jones, J. M. (2009, January 28). State of the states: Political party affiliation. Gallup. Retrieved from http://www.gallup.com/poll/114016/state-states-political-partyaffiliation.aspx

Jones, J. M. (2013, October 29). U.S. death penalty support lowest in more than 40 years. Gallup. Retrieved from http://www.gallup.com/poll/165626/death-penaltysupport-lowest-years.aspx?utm_source=position2\&utm_medium=related\&utm_ campaign $=$ tiles

Jones, J. M. (2014, October 23). Americans' support for death penalty stable. Gallup. Retrieved from http://www.gallup.com/poll/178790/americans-support-deathpenalty-stable.aspx

Keijser, J. W., van der Leeden, R. \& Jackson, J. L. (2002). From moral theory to penal attitudes and back: A theoretically integrated modeling approach. Behavioral Science and the Law. 20 (4): 317-335.

Keil, T.J., \& Vito, G.F. (1991). Fear of crime and attitudes toward capital punishment: A structural equations model. Justice Quarterly. 8 (4): 447-464. 
Keller, L. B., Oswald, M. E., Stucki, I. \& Gollwitzer, M. (2010). A closer look at an eye for an eye: Laypersons' punishment decisions are primarily driven by retributive motives. Social Justice Research. 23 (2-3): 99-116.

Kentucky State Data Center. (2012). Kentucky Decennial Census Data. Retrieved April 23, 2014 from University of Louisville website: http://ksdc.louisville.edu/index .php/kentucky-demographic-data/decennial-census

Lipka, M. (2014, February 12). Support for death penalty drops among Americans. Pew Research Center. Retrieved from http://www.pewresearch.org/fact$\operatorname{tank} / 2014 / 02 / 12 /$ support-for-death-penalty-drops-among-americans/

Noss, A. (2014, September). Household income: 2013. Retrieved from United States Census Bureau website: http://www.census.gov/content/dam/Census/library /publications/2014/acs/acsbr13-02.pdf

Paternoster, R. (2010). How much do we really know about criminal deterrence? The Journal of Criminal Law \& Criminology. 100 (3): 765-823.

Pew Research Center. (2013). Views on end-of-life medical treatments Appendix B: Question wording and survey topline. Retrieved from http://www.pewforum .org/files/2013/11/end-of-life-survey-report-app-b.pdf

Pew Research Center. (2014, March 28). Number of executions in each state since 1977. Retrieved November 4, 2014 from http://www.pewforum.org/2014/03/28/ executions-state-by-state/

Radelet, M. L. \& Borg, M. J. (2000). The changing nature of death penalty debates. Annual Review of Sociology. 26: 43-61. 
Rayburn, C. (2004). Better dead than r(ap)ed?: The patriarchal rhetoric driving capital rape statutes. St. John's Law Review. 78 (4): 1119-1165.

Ré, R. M. (2009). Can Congress overturn Kennedy v. Louisiana? Harvard Journal of Law \& Public Policy. 33 (3): 1031-1105.

Sedlak, A.J., Mettenburg, J., Basena, M., Petta, I., McPherson, K., Greene, A., and Li, S. (2010). Fourth National Incidence Study of Child Abuse and Neglect (NIS-4): Report to Congress, Executive Summary. Washington, DC: U.S. Department of Health and Human Services, Administration for Children and Families.

Skinner, C. J. (2012). An obligation to live: Retaining the cultural meaning of capital punishment by prohibiting volunteerism on death row and the implications of its continued practice. Lincoln Law Review. 39: 55-92.

Smith, D. W., Letourneau, E. J., Saunders, B. E., Kilpatrick, D. G., Resnick, H. S. \& Best, C. L. (2000). Delay in disclosure of childhood rape: Results from a national survey. Child Abuse and Neglect. 24 (2): 273-287.

Snell, T. L. (2014) Capital punishment, 2012 - statistical tables. Bureau of Justice Statistics, NCJ 245789.

Snyder, H. N. (2000). Sexual assault of young children as reported to law enforcement: Victim, incident, and offender characteristics. Bureau of Justice Statistics. NCJ182990.

Strelan, P. \& van Prooijen, J. W. (2013). Retribution and forgiveness: The healing effects of punishing for just deserts. European Journal of Social Psychology. 43 (6): 544-553. 
Swanson, E. (2014, January 25). Americans favor the death penalty, but few want the executed to suffer. Huffington Post. Retrieved from http://www.huffingtonpost .com/2014/01/25/death-penalty-poll_n_4661940.html

Swift, A. (2014, October 23). American's: 'Eye for an eye' top reason for death penalty. Gallup. Retrieved from http://www.gallup.com/poll/178799/americanseye-eye-top-reason-death-penalty.aspx

Tabak, R. J. (1998). How empirical studies can affect positively the politics of the death penalty. Cornell Law Review. 83 (6): 1431-1447.

U.S. Department of Health and Human Services, Administration for Children and Families, Administration on Children, Youth and Families, Children's Bureau. (2013). Child maltreatment 2012.

Vito, G.F. \& Keil, T.J. (1998). Elements of support for capital punishment: An examination of changing attitudes. Journal of Crime \& Justice. 21 (2): 17-36.

YouGov. (2014). Favorability of the death penalty. Retrieved from http://cdn.yougov. com/cumulus_uploads/document/k72j8dj65u/tabs_HP_death_penalty_20140121. pdf 


\section{Cases Cited}

Atkins v. Virginia, 536 U.S. 304 (2002).

Coker v. Georgia, 433 U.S. 584 (1977).

Furman v. Georgia, 408 U.S. 238 (1972).

Kennedy v. Louisiana, 128 U.S. 2641 (2008).

Roper v. Simmons, 543 U.S. 551 (2005).

State v. Wilson, 685 So. 2d 1063 (La. 1996). 


\section{APPENDIX A}

\section{Survey A}

These first 15 questions present a series of criminal situations and sanctions for offenders. You are asked to indicate whether you agree or disagree that the proposed sanction is appropriate for the listed hypothetical offender.

\section{Situation 1}

Marcus is a 47 year-old married man. He admitted to his wife that he has raped their daughter and molested their son.

1. A judge sentences Marcus to 10 years' probation.
a. Strongly Agree
Agree
Disagree
Strongly Disagree

2. A judge sentences Marcus to ten years in prison.
a. Strongly Agree
Agree
Disagree
Strongly Disagree

3. A judge sentences Marcus to death.
a. Strongly Agree
Agree
Disagree
Strongly Disagree

\section{Situation 2}

Paul is a 30 year-old married man. He raped his eight year-old step-daughter and lied to the police about the perpetrator and evidence.

1. A judge sentences Paul to 10 years' probation.
a. Strongly Agree
Agree
Disagree
Strongly Disagree 
2. A judge sentences Paul to ten years in prison.
a. Strongly Agree
Agree
Disagree
Strongly Disagree

3. A judge sentences Paul to death.
a. Strongly Agree
Agree
Disagree
Strongly Disagree

\section{Situation 3}

Scott is a 25 year-old single man. He rapes a thirteen year-old girl he does not know.

1. A judge sentences Scott to 10 years' probation.
a. Strongly Agree
Agree
Disagree
Strongly Disagree

2. A judge sentences Scott to ten years in prison.
b. Strongly Agree
Agree
Disagree
Strongly Disagree

3. A judge sentences Scott to death.
c. Strongly Agree
Agree
Disagree
Strongly Disagree

\section{Situation 4}

John is a 63 year-old married man. He raped two of his female relatives repeatedly over a period of more than five years.

1. A judge sentences John to 10 years' probation.
a. Strongly Agree
Agree
Disagree
Strongly Disagree

2. A judge sentences John to ten years in prison.
b. Strongly Agree
Agree
Disagree
Strongly Disagree

3. A judge sentences John to death.
c. Strongly Agree
Agree
Disagree
Strongly Disagree 


\section{Situation 5}

Dennis and Katherine are a married couple in their mid-30s. They raped and molested one of their foster children.

1. A judge sentences Dennis and Katherine to 10 years' probation.
a. Strongly Agree
Agree
Disagree
Strongly Disagree

2. A judge sentences Dennis and Katherine to ten years in prison.
b. Strongly Agree
Agree
Disagree
Strongly Disagree

3. A judge sentences Dennis and Katherine to death.
c. Strongly Agree
Agree
Disagree
Strongly Disagree

\section{Demographics}

These last 9 questions ask about you and will allow the study to examine patterns in the responses of individuals.

1. What is your age?

4. Are you a parent?
a. Yes
b. No

2. What is your biological sex?
a. Male
b. Female

5. Before taxes, what was your personal income last year?

3. What is your race?
a. Caucasian
b. African American
c. Asian
d. Hispanic
e. Native American
f. Other
a. $0-\$ 25,000$
b. $\$ 25-\$ 50,000$
c. $\$ 50-\$ 75,000$
d. $\$ 75-\$ 100,000$
e. $\$ 100,000+$

6. What is the highest level of education you have completed? 

a. Less than high school diploma/GED
b. High school diploma/GED
c. Some college
d. College degree
e. Graduate school or beyond

7. What are your political views?

$\begin{array}{lllllllllll}0 & 1 & 2 & 3 & 4 & 5 & 6 & 7 & 8 & 9 & 10\end{array}$ Liberal

\section{Conservative}

8. As a child, were you ever a victim of rape or any sexual offense?
a. Yes
b. No

9. As an adult, have you been a victim of rape or any sexual offense?
a. Yes
b. No 


\section{Survey B}

These first 15 questions present a series of criminal situations and sanctions for offenders. You are asked to indicate whether you agree or disagree that the proposed sanction is appropriate for the listed hypothetical offender.

\section{Situation 1}

Marcus is a 47 year-old married man. He admitted to his wife that he has raped their three year-old daughter and molested their infant son multiple times.

1. A judge sentences Marcus to 10 years' probation.
a. Strongly Agree
Agree
Disagree
Strongly Disagree

2. A judge sentences Marcus to ten years in prison.
a. Strongly Agree
Agree
Disagree
Strongly Disagree

3. A judge sentences Marcus to death.
a. Strongly Agree
Agree
Disagree
Strongly Disagree

Situation 2

Paul is a 30 year-old married man. He brutally raped his eight year-old step-daughter and later lied to the police about the perpetrator and evidence. His step-daughter required major surgery due to her extensive injuries.

1. A judge sentences Paul to 10 years' probation.
a. Strongly Agree
Agree
Disagree
Strongly Disagree 
2. A judge sentences Paul to ten years in prison.
a. Strongly Agree
Agree
Disagree
Strongly Disagree

3. A judge sentences Paul to death.
a. Strongly Agree
Agree
Disagree
Strongly Disagree

Situation 3

Scott is a 25 year-old single man. He abducts a thirteen year-old girl, rapes her and shoots her in the head, leaving her to die. She survives.

1. A judge sentences Scott to 10 years' probation.
a. Strongly Agree
Agree
Disagree
Strongly Disagree

2. A judge sentences Scott to ten years in prison.
a. Strongly Agree
Agree
Disagree
Strongly Disagree

3. A judge sentences Scott to death.
a. Strongly Agree
Agree
Disagree
Strongly Disagree

\section{Situation 4}

John is a 63 year-old married man. He raped two of his female relatives repeatedly over a period of more than five years. He threatened them not to tell or he would kill them. He was previously convicted of sexual assault 15 years ago.

1. A judge sentences John to 10 years' probation.
a. Strongly Agree
Agree
Disagree
Strongly Disagree

2. A judge sentences John to ten years in prison.
a. Strongly Agree
Agree
Disagree
Strongly Disagree

3. A judge sentences John to death. 

a. Strongly Agree
Agree
Disagree
Strongly Disagree

\section{Situation 5}

Dennis and Katherine are a married couple in their mid-30s. They raped and molested one of their foster children over a period of eight years. Now an adult, the victim testifies he has attempted suicide several times and suffers from depression.

1. A judge sentences Dennis and Katherine to 10 years' probation.
a. Strongly Agree
Agree
Disagree
Strongly Disagree

2. A judge sentences Dennis and Katherine to ten years in prison.
a. Strongly Agree
Agree
Disagree
Strongly Disagree

3. A judge sentences Dennis and Katherine to death.
a. Strongly Agree
Agree
Disagree
Strongly Disagree

\section{Demographics}

These last 9 questions ask about you and will allow the study to examine patterns in the responses of individuals.

1. What is your age?
d. Hispanic
e. Native American
f. Other

2. What is your biological sex?
a. Male
b. Female

4. Are you a parent?
a. Yes
b. No

3. What is your race?
a. Caucasian
b. African American
c. Asian

5. Before taxes, what was your personal income last year?
a. $0-\$ 25,000$ 

b. $\$ 25-\$ 50,000$
c. $\$ 50-\$ 75,000$
d. $\$ 75-\$ 100,000$
e. $\$ 100,000+$

6. What is the highest level of education you have completed?
a. Less than high school diploma/ GED
b. High school diploma/GED
c. Some college
d. College degree
e. Graduate school or beyond

7. What are your political views?

$\begin{array}{lllllllllll}0 & 1 & 2 & 3 & 4 & 5 & 6 & 7 & 8 & 9 & 10\end{array}$

Liberal

\section{Conservative}

8. As a child, were you ever a victim of rape or any sexual offense?
a. Yes
b. No

9. As an adult, have you been a victim of rape or any sexual offense?
a. Yes
b. No 


\section{CURRICULUM VITA}

NAME: Charlene Kaye Chudacoff

ADDRESS: 8517 Chase Road

Louisville, KY 40258

DOB: $\quad$ Louisville, Kentucky - November 8, 1987

\section{EDUCATION}

\& TRAINING: $\quad$ B.S., Justice Administration

University of Louisville

2006-2011

M.S., Justice Administration

University of Louisville

2013-2015 